\title{
PENGELOLAAN KONFLIK PEMANFAATAN SUMBER DAYA HUTAN DALAM MEWUJUDKAN HAK MASYARAKAT LOKAL
}

\author{
Agus Surono $^{1}$
}

\begin{abstract}
Management of forest resources is a system of forest management in order to provide better protection of forest life support system that is in a national park or forest production. Since the implementation of regional autonomy under Law 32 of 2004 on Regional Government, the main problems encountered in the development of conservation in Indonesia is a division of central and local authorities. Under existing regulations, the conservation authority is still in the hands of the central government, but there are many initiatives at the local level regarding regulatory management of conservation areas that have not been accommodated by the central government. On the one hand, the central government over maintaining conservation areas in accordance with the formation, while the areas with the concept of "development" to improve the welfare of the community and trying to release PAD area of state forest land. Meanwhile, the people who were around the area feel entitled to be able to enjoy the fruits of the region in a period of decentralization. The concept of comanagement with communities and local governments in fact been tried in several National Parks in Indonesia. This paper uses descriptive method of analysis with normative juridical approach legislation (statute approach), conceptual approaches (analytical and conceptual approach), approach cases (cases approach), and the comparative approach (comparative approach) using deductive reasoning and/or inductive and find the truth in order to obtain objective.
\end{abstract}

Keywords: conservation, forest resources management, conflict

\begin{abstract}
Abstrak
Pengelolaan sumberdaya hutan adalah sistem pengelolaan hutan dalam rangka memberikan perlindungan sistem penyangga kehidupan baik hutan yang berada di kawasan taman nasional maupun hutan produksi. Sejak implementasi otonomi daerah berdasarkan UU No.32 Tahun 2004 tentang Pemerintahan Daerah, persoalan utama yang dihadapi dalam pengembangan konservasi di Indonesia adalah pembagian kewenangan pusat dan daerah. Berdasarkan peraturan perundangan yang berlaku, kewenangan konservasi masih ada di tangan

\footnotetext{
${ }^{1}$ Penulis adalah Dosen Tetap Fakultas Hukum Universitas Al Azhar Indonesia, Dosen S2 pada Universitas Borobudur, Universitas Islam Riau, Universitas Muhammadiyah Palembang, Kepala Divisi Hukum Pusat Pengelolaan Komplek Kemayoran, Sekretariat Negara RI. Alamat kontak: agusurono@yahoo.com
} 
pemerintah pusat, padahal ada banyak inisiatif di tingkat daerah mengenai peraturan pengelolaan kawasan konservasi yang belum terakomodir oleh pemerintah pusat. Di satu sisi pemerintah pusat lebih mempertahankan kawasan konservasi sesuai dengan pembentukannya, sedangkan pihak daerah dengan konsep "pembangunan" untuk meningkatkan kesejahteraan masyarakat dan PAD berusaha untuk melepaskan kawasan tersebut dari kawasan hutan negara. Sementara itu masyarakat yang berada di sekitar kawasan merasa berhak untuk dapat menikmati hasil dari kawasan tersebut dalam masa desentralisasi. Konsep pengelolaan bersama dengan masyarakat dan pihak pemerintah daerah sebenarnya telah dicoba di beberapa Taman Nasional yang ada di Indonesia. Tulisan ini mempergunakan metode deskriptif analisis dengan pendekatan yuridis normatif melalui pendekatan perundang-undangan (statute approach), pendekatan konseptual (analytical and conceptual approach), pendekatan kasus (cases approach), dan pendekatan komparatif (comparative approach) dengan menggunakan penalaran deduktif dan/atau induktif guna mendapatkan dan menemukan kebenaran obyektif.

Kata kunci: konservasi, sumber daya hutan, pengelolaan, konflik

\section{Pendahuluan}

Disekitar kawasan hutan, hidup masyarakat asli atau masyarakat adat yang berdasarkan hukum adatnya memiliki hak sumber daya alam disekitar hutan. Hukum adat menetapkan bahwa masyarakat adat tersebut mempunyai hak atas hutan disekitar mereka berupa hak untuk menggunakan lahan di teritorialnya, hak untuk tinggal dalam jangka waktu tertentu di sekitar kawasan, serta hak untuk mamanfaatkan hutan di sekitar kawasan. ${ }^{2}$ Dalam perkembangannya disuatu kawasan lahir masyarakat lokal yautu masyarakat yang berasal dari daerah lain, tetapi kemudian menetap untuk jangka waktu yang lama dikawasan tersebut, seperti terjadi dikawasan Tangkahan.

Perkembangan sosial ekonomi telah melahirkan konflik antara masyarakat lokal dan negara mengenai pelaksanaan hak-hak mereka tersebut, seperti yang terjadi di Kawasan Taman Nasional Gunung Leuser.

Penelitian mengenai hak-hak masyarakat lokal dalam Pengelolaan Taman Nasional Gunung Leuser tersebut penting setidak-tidaknya karena empat sebab. Pertama, belum adanya konsep yang jelas tentang perlindungan hak masyarakat

\footnotetext{
${ }^{2}$ Van Voollenhoven membedakan apa yang disebut dengan hak ulayat (disposal right) dan yang dipegang oleh anggotanya. Van vollenhoven memberikan enam ciri hak ulayat, yaitu 1) masyarakat dan anggotanya diperbolehkan secara bebas untuk menggunakan lahan-lahan perawan (virgin lands) di dalam teritorialnya; 2) pihak luar diijinkan untuk menggunakan lahan-lahan tersebut setelah mendapat ijin jaminan oleh masyarakat; 3) kompensasi bagai penggunaan tersebut harus dibayar oleh pihak luar; 4) masyarakat selalu memelihara control lahan-lahan bekas ditanam di dalam teritorialnya; 5) orang yang bersalah harus bertanggungjawab dan menanggung biaya, dan menjadi tanggung jawab bersama jika pelanggar tak dikenal; 6) masyarakat tidak dapat mengalihkan secara permanent hak ulayatnya.
} 
lokal dalam pengelolaan sumber daya hutan di kawasan Tangkahan, Taman Nasional Gunung Leuser. Belum adanya konsep tentang perlindungan masyarakat lokal dapat dibuktikan bahwa dalam kenyataannya masih banyak kesulitan ekonomi masyarakat sekitar kawasan Tangkahan, Taman Nasional Hunung Leuser.

Kedua, adanya konflik yang terjadi di berbagai kawasan Tangkahan, Taman Nasional Gunung Leuser yang melibatkan berbagai pihak, termasuk juga masyarakat lokal. Keterlibatan masyarakat lokal dalam konflik ini dikarenakan adanya beberapa faktor seperti adanya pengungsi dari Aceh, para pelaku perambah hutan, adanya praktek illegal logging, yang bersumber pada alasan untuk memenuhi kebutuhan hidup sehari-hari.

Ketiga, adanya masalah otonomi daerah, dalam hubungannya dengan pengaturan hak masyarakat lokal untuk ikut serta mengelola sumber daya hutan di kawasan Tangkahan, Taman Nasional Gunung Leuser. Selama ini masyarakat yang hidup di sekitar kawasan Tangkahan, Taman Nasional Gunung leuser mempunyai tradisi memanfaatkan sumber daya hutan yang sudah berlangsung secara turun temurun. Pandangan ini menyebabkan mereka beranggapan mempunyai hak untuk memanfaatkan sumber daya hutan untuk memenuhi kebutuhan hidupnya. Namun dengan otonomi daerah yang menjadikan daerah mempunyai hak yang lebih untuk memanfaatkan sumber daya hutan, maka berimbas kepada adanya larangan bagi masyarakat sekitar hutan untuk memanfaatkan hutan, sehingga sering menimbulkan konflik.

Keempat, belum adanya pola yang jelas mengenai penyelesaian sengketa antara masyarakat lokal dan negara mengenai pengelolaan sumber daya hutan. Pola-pola penyelesaian yang ditawarkan saat ini masih cenderung berpihak kepada kepentingan pemerintah, atau bahkan belum menyentuh hal yang bersifat mendasar.

Kelima, bila dapat diciptakan konsep dan pola yang jelas dalam pengelolaan sumber daya hutan oleh masyarakat lokal, maka konsep dan pola tersebut mungkin dapat diterapkan pula pada Taman Nasional di daerah lainnya di Indonesia.

Taman Nasional Gunung Leuser merupakan salah satu dari 5 (lima) Taman Nasional yang ditetapkan pertama kali oleh Pemerintah Indonesia pada tahun 1980. Ketika itu Menteri Pertanian mendeklarasikan TN Gunung Leuser, TN Gunung Gede Pangrango, TN Ujung Kulon, TN Baluran, dan TN Komodo seluas total 1,4 juta Ha menjadi Kawasan Taman Nasional. ${ }^{3}$

Sejarah konservasi di kawasan Leuser dimulai sejak tahun 1914 ketika para pemuka adat Aceh meminta pemerintah Kolonial Belanda untuk melindungi hutan Singkil dan Alas Laden dengan melarang eksploitasi kayu dan aktivitas logging di kawasan tersebut. Pada tahun 1928 seorang ahli geologi (yang juga penanam karet) berkebangsaan Belanda, tuan F.C Van Heurn menyusun sebuah konsep permohonan untuk usaha-usaha perlindungan kawasan di wilayah Aceh Barat, yang disampaikan pada suatu forum "Netherlandse Commissi Voor Internationale

\footnotetext{
${ }^{3}$ Balai Taman Nasional Gunung Leuser, "Sejarah Taman Nasional Gunung Leuser", (Kuta Cane: Penerbit TNGL, 2004), hal. 12.
} 
Natuur Bescherming", tepatnya pada tanggal 9 Mei 1928. Pada perkembangan selanjutnya, konsep-konsep ini disempurnakan dan diajukan lagi pada tahun 1932, dan pada tahun 1934 kawasan perlindungan sumberdaya alam Gunung Leuser secara resmi ditetapkan. Gubernur Aceh saat itu, Van Aken menetapkan areal seluas 416.500 Ha sebagai kawasan perlindungan. Sementara sumber lain, seperti disebutkan dalam RPTN Gunung Leuser 1995-2020 (Buku I) menyebutkan bahwa untuk pertama kali pada tahun 1934 tuan A. Ph. Van Ahen, Gubernur Aceh saat itu menetapkan secara resmi pembentukan kawasan Suaka Margasatwa Gunung Leuser dengan luas kawasan $142.800 \mathrm{Ha}$ melalui Surat Keputusan (Wildreservaat Goenoeng Leoeser) ZB No. $317 / 35$ tanggal 3 Juli $1934 .^{4}$

Kemudian pada tahun 1936, ditetapkan lagi kawasan hutan rawa Kluet seluas $20.000 \mathrm{Ha}$, dan pada tahun 1938 kawasan perlindungan sumber daya alam ini mengalami penambahan areal melalui penetapan dari Pemerintah Hindia Belanda waktu itu, yaitu dengan pembentukan Suaka Alam Sekundur (79.100 Ha), dan Suaka Alam Langkat Barat dan Selatan $(127.075 \mathrm{Ha}){ }^{5}$

Lebih dari 3 dekade kemudian, dibangun 2 (dua) buah stasiun yang kemudian berperan penting dalam kebijakan bidang penelitian dan pengembangan, perlindungan, dan ekoturisme di kawasan TNGL. Pada tahun 1972 Herman dan Ans Rijksen, yang berkebangsaan Belanda memulai pembangunan pusat penelitian dan rehabilitasi serta perkembangan/monitoring Orang Utan di Ketambe. Satu tahun kemudian, pusat penelitian Orang Utan lainnya, mulai dirintis oleh Monica Borner dan Regina Frey di Sungai Bohorok, Langkat. Pada tahun 1976 Pemerintah Indonesia melalui Menteri Pertanian menetapkan Suaka Margasatwa Kappi seluas $150.000 \mathrm{Ha}^{6}$

Pada tanggal 6 Maret 1980, Pemerintah melalui Menteri Pertanian mengumumkan secara resmi tentang pembentukan Taman Nasional Gunung Leuser dalam forum KTT Bumi. ${ }^{7}$

${ }^{4}$ Ibid., hal. 3 .

${ }^{5}$ Ibid.

${ }^{6}$ Ibid.

${ }^{7}$ Selanjutnya melalui SK Menteri Pertanian No. 913/Kpts/UM/10/1982 tanggal 30 Oktober 1982, Taman Nasional Gunung Leuser ditetapkan dengan luasan 792.675 Ha. Dan, melalui SK Direktur Jenderal PHPA No. 46/Kpts/VI-Sek/84 tanggal 11 Desember 1984 menetapkan areal Taman Nasional telah bertambah luasan menjadi $862.975 \mathrm{Ha}$ meliputi 5 kawasan perlindungan satwa liar di Gunung Leuser, Gunung Kappi, Langkat, Kluet, dan Sikundur, 1 buah areal hutan wisata di Lawe Gurah, serta 2 hutan lindung di wilayah Serbolangit dan Sembabala. Pada tahun 1987, melalui SK Dirjen PHPA No.48/Kpts/DJ-VI/1987 tanggal 12 desember tentang penunjukan mintakat, diperoleh wilayah berdasarkan pemintakatan ini seluas $802.185 \mathrm{Ha}$. Sepuluh tahun kemudian melalui SK Menteri Kehutanan No. 276/Kpts-VI/1997 tanggal 23 Mei 1997, luas wilayah TNGL yang ditetapkan adalah 1.094.692 Ha. Kemudian luasan ini berubah lagi setelah diterbitkannya Keputusan Presiden No. 33 tahun 1998 tanggal 28 Februari tentang pengelolaan ekosistem Leuser, yaitu menjadi seluas 1.097.000 Ha. Mulai tahun 1997, telah banyak dihasilkan bermacam deklarasi melalui pertemuan dengan para alim ulama, tokoh adat, tokoh agama, Pemda, 
Dalam perkembangannya Taman Nasional Gunung Leuser melahirkan berbagai masalah, sedikitnya dalam 3 bentuk. Pertama, masalah yang berkaitan dengan perambahan atau penguasaan lahan yang melibatkan masyarakat lokal. Aktivitas para pengungsi maupun "perambah yang berkedok sebagai pengungsi" ini makin hari makin meresahkan. Kondisi kawasan TNGL menjadi sangat memprihatinkan sehingga mekanisme ekosistem dan habitat satwa serta pengembangan hayati sudah sangat terganggu. Menurut catatan Yayasan Lauser Indonesia (YLI), pengungsi menguasai lahan TNGL rata-rata 10 - 15 rantai tanah $(0,5 \mathrm{Ha} / \mathrm{KK})$, sebagai lahan untuk bertanam. Sembilan puluh persen $(90 \%)$ pengungsi bekerja sebagai pelaku dan buruh illegal logging. Dokumentasi YLI yang menyebutkan sebanyak 50 unit chainsaw setiap hari beroperasi menghancurkan kawasan TNGL, dengan estimasi volume kayu yang keluar setiap hari sebesar $50 \mathrm{~m}^{3} .8$

Pada waktu Aceh masih dalam keadaan konflik, pengungsi bertambah jumlahnya, mengingat lokasi taman nasional sangat strategis bagi tempat tinggal para pengungsi. Konflik keamanan yang terjadi di wilayah Aceh sebagian besar disikapi oleh masyarakat dengan meninggalkan domisili dan mencari hunian baru untuk menyelamatkan diri. Beberapa diantara kelompok yang eksodus dari Aceh tersebut ada yang berdiam di kawasan TNGL Langkat. Semula komunitas masyarakat yang eksodus dari Aceh menuju kawasan TNGL terbilang kecil, namun belakangan jumlah $\mathrm{KK}$ semakin bertambah karena telah terjalin komunikasi dengan para penghuni lama tentang tempat hunian baru di kawasan ini. Seiring berjalannya waktu, masyarakat pengungsi sepertinya mulai senang berdiam di tempat hunian ini. Mereka mulai menanami pekarangan untuk memenuhi kebutuhan hidupnya. Selanjutnya, mereka mulai berpikir untuk mendapat tambahan lain sambil menunggu hasil tanaman pekarangan, yaitu dengan membuka hutan dan mengeksploitasi kayu. Keadaan inilah yang kemudian dimanfaatkan oleh pihak lain sehingga minat masyarakat untuk eksodus ke wilayah ini dan ikut bermain seperti rekan-rekannya semakin bertambah. Dan, beberapa kemudahan yang menjurus kepada penipuan identitas dilakukan untuk masuk ke areal ini "berkedok sebagai pengungsi", difasilitasi oleh pihak-pihak yang mencoba memanfaatkan keadaan dan memiliki kepentingan. ${ }^{9}$ Masalah pengungsi, pemukiman dan illegal logging sebagian besar terjadi di Damar Hitam, Sei Lepan, Sekoci, Sei Minyak, Tower, Barak Induk, Barak Gajah, Sei Bamban dan Lou Gedang. Pada tahun 2000, sebanyak 38 KK pengungsi melakukan perambahan di kawasan Damar Hitam, Kecamatan Sei Lepan. Berdasarkan laporan pihak YLI pada akhir tahun 2004 sebanyak $\pm 2000 \mathrm{kk}$ perambah liar (bukan pengungsi) telah menguasai lahan TNGL. Berdasarkan laporan dari

dan tokoh masyarakat di berbagai wilayah TNGL, misalnya adalah Deklarasi Leuser pada tahun 1997, Deklarasi Langkat 1998, Deklarasi Karo 1999, dan Deklarasi Dairi 1999.

${ }^{8}$ Ibid.

${ }^{9}$ Ibid. 
petugas lapangan TNGL, terdata $600 \mathrm{KK}$ sebagai perambah liar, dan estimasi luas kerusakan $\pm 35.000 \mathrm{Ha}$.

Perladangan liar telah lama terjadi di kawasan ini, tercatat mulai marak dan mengancam keberadaan kawasan pada dekade 90-an. Ancaman ini berupa klaim kawasan, dan kemudian berkembang karena para penggarap didukung oleh spekulan lahan. ${ }^{10}$

Kedua, masalah illegal logging terutama dalam skala besar yang dilakukan oleh pihak luar (pengusaha) yang melibatkan masyarakat lokal dan didukung oleh oknum aparat. Masyarakat lokal di sekitar lokasi saat ini cenderung sebagai "massa mengambang", yang sebagian menentang keberadaan pengungsi dan perambah ilegal serta sebagian mendukung bahkan ikut terlibat. Masyarakat yang mendukung melihat fenomena ini sebagai alternatif sumber ekonomi baru dalam memenuhi kebutuhan akan lahan dan mendapatkan pendapatan tambahan.

Pemanfaatan tradisional yang diperbolehkan hanyalah pemanfaatan potensi kawasan berupa hasil hutan non kayu dan jasa lingkungan untuk kepentingan pemenuhan kebutuhan sehari-hari atau mempertahankan kebutuhan hidup atau pemenuhan kebutuhan spiritual masyarakat lokal/setempat/sekitar kawasan konservasi yang dilaksanakan oleh masyarakat lokal/setempat/sekitar Taman Nasional sendiri dengan mempergunakan peralatan tradisional dan sesuai dengan prinsip-prinsip konservasi. ${ }^{11}$

Ketiga, kedua manfaat tersebut di atas mengakibatkan kaburnya hak-hak masyarakat lokal untuk mengelola kawasan hutan disekitar kampung mereka. Dari sudut pandang wewenang,siapakah yang berhak mengatur dan mengawasi kawasan hutan suatu Taman Nasional. Adakah suatu kebijakan Pemerintah Pusat terhadap eksistensi Taman Nasional dan hak-hak masyarakat lokal atas kawasan tersebut, atau apakah kebijakan dan pengawasan sudah diserahkan kepada Pemerintah Daerah berdasarkan Undang-Undang No. 22 Tahun 1999 sebagaimana telah dirubah dengan Undang-Undang No.32 tahun 2001 tentang Pemerintahan Daerah?

Keempat, bagaimana seharusnya penyelesaian konflik yang timbul di kawasantaman nasional tersebut? Adakah suatu kebijakan untuk mengelola konflik yang lahir antara masyarakat asli dan masyarakat pendatang atau konflik antara masyarakat dan negara yang timbul di kawasan taman nasional tersebut?

Keempat permasalahan tersebut telah menjadi satu mata rantai yang terkait dengan demikian kuatnya, sehingga diperlukan upaya pemecahan yang

\footnotetext{
${ }^{10}$ Pada tanggal 12 November 2000 telah dilakukan relokasi pengungsi sebanyak $\pm 200 \mathrm{KK}$ ke Provinsi Riau. Kegiatan relokasi lainnya pernah dilakukan dengan memindahkan para pengungsi ke Kabupaten Tapanuli Selatan. Berdasarkan estimasi oleh Dinas Kehutanan Kabupaten Langkat, jumlah perambah saat ini mencapai $\pm 3.000 \mathrm{KK}$ dan jumlah pengungsi lebih dari 400 KK. Pendataan tentang jumlah perambah, pengungsi, dan pemukim dari masyarakat sekitar hutan sulit dilakukan karena penolakan massa untuk memasuki wilayah. Wawancara dengan Wiratno, Kepala Balai taman Nasional Gunung Leuser, 26 Juni 2006.

${ }^{11}$ Dikaitkan dengan Undang-Undang No.5 Tahun 1990 tentang Konservasi Sumber Daya Alam Hayati dan Ekosistemnya, kegiatan pemanfatan tradisional dilaksanakan pada zona pemanfaatan tradisional Taman Nasional.
} 
terintegrasi, cara pandang yang mengena ke substansi masalah, dan penyelesaian secara menyeluruh dan terpadu oleh semua pihak.

Pihak-pihak yang antara lain mempunyai posisi sentral sebagai pihak yang berkonflik dapat dibedakan: ${ }^{12}$

Pertama, adalah pihak Pengungsi Aceh. Sikap para pengungsi ini secara umum adalah menentang pengusiran paksa atas areal yang telah diusahakan, dan menuntut perhatian negara terhadap jaminan hidup selanjutnya. Seperti halnya masyarakat lokal, sebagian kelompok pengungsi telah teragitasi hingga menuntut status areal yang mereka diami saat ini dilegalkan. Saat ini yang dibutuhkan oleh mereka adalah kejelasan status sosial sebagai bagian dari penduduk yang sah. Sebenarnya tidak terlalu menjadi masalah bagi mereka apabila harus meninggalkan wilayah TNGL yang mereka diami saat ini. Namun untuk menyambung hidup, mereka terpaksa bertahan dan bersedia melakukan apa saja. Kondisi ini dimanfaatkan oleh pihak-pihak yang notabene memiliki modal uang dan pengetahuan untuk memuluskan tujuan mereka mengeksploitasi sumber daya alam dalam pemenuhan lahan untuk perkebunan dan mengambil kayu secara illegal dari dalam kawasan.

Kedua, adalah pihak perambah illegal. Kelompok ini adalah para pendatang yang dibayar untuk membuka lahan oleh para cukong. Berlatang belakang kebutuhan ekonomi ditambah pengaruh dari para "aktor intelektual", mereka tidak mengakui wilayah tersebut sebagai bagian dari wilayah TNGL, menuntut perubahan status, dan pengakuan administratif pemerintah terkait. ${ }^{13}$

\section{${ }^{12}$ Ibid.}

${ }^{13}$ Faktor-faktor penghambat dalam upaya pemecahan masalah diuraikan sebagai berikut : Pertama, belum kondusifnya keamanan di Aceh menjadi alasan bagi sebagian orang yang ingin mandapat lahan. Mereka mengikuti jejak para pendahulu sesama pengungsi yang telah memiliki lahan dan mata pencaharian di tempat baru. Identitas mereka kadang sulit ditelusuri apakah benarbenar pengungsi dari Aceh atau perambah. Kedua, tata batas dan tanda batas yang jelas di lapangan mutlak diperlukan untuk menata ulang dan menjamin keutuhan kawasan. Di lapangan saat ini tanda batas sudah banyak yang hilang dan bergeser. Proses hukum ke depan akan sangat tergantung dari kejelasan status kepemilikan kawasan yang direpresentasikan oleh pal batas yang jelas di lapangan. Ketiga, lemahnya supervisi pihak TNGL selaku pengelolaan kawasan selama ini menjadi salah satu sebab maraknya perambahan. Hal ini diperparah oleh kurang pahamnya aparatur non kehutanan dalam memandang sistem pengelolaan kawasan. Pola keproyekan dan luncuran dana dari pusat turut menambah kusutnya permasalahan. Kemitraan yang terjalin, yang pada awalnya diharapkan bisa meminimalisir hambatan dalam pola keproyekan pun belum berjalan selaras. Dalam hal ini masing-masing pihak berjalan sendiri beradu konsep penyelesaian dan kadang melemparkan tanggung jawab begitu saja. Di sinilah menjadi sangat penting untuk selalu mengedepankan upaya penyelesaian kolaboratif dengan memanfaatkan potensi tiap institusi/stakeholder terkait. Keempat, masalah jangka waktu penyelesaian. Hambatan ini erat kaitannya dengan pola keproyekan dan komitmen stakeholder dalam penyelesaian masalah secara tuntas. Sering schedule yang telah tersusun tidak bisa berjalan karena terhambat dalam hal pendanaan dan inkonsistensi prioritas kegiatan oleh insitusi tertentu. Padahal tuntasnya masalah ini butuh konsistensi dan jaminan kelancaran perangkat pendukungnya. Pada akhirnya para obyek pelaku baik aktor intelektual/pemodal maupun para pelaku di lapangan semakin berani menjalankan aksinya karena menganggap semua ini hanya proyek yang akan selesai pada waktunya tanpa ada kelanjutan. Kelima, keterlibatan oknum pemerintah. Hasil investigasi menunjukkan bahwa sebagian aktor pelaku adalah oknum pemerintah yang jelas-jelas telah 
Ketiga, Pemerintah Kabupaten dan Propinsi dimana kawasan Taman Nasional itu terletak dan dimana konflik-konflik itu berlangsung, sementara Pemerintah Pusat yang bertanggungjawab mengelola suatu Taman Nasional. Adakah pembagian kewenangan antara Pemerintah Pusat dan Pemerintah daerah dalam pengelolaan suatu kawasan taman nasional?

\section{Metode Pendekatan}

Tulisan ini mempergunakan metode deskriptif analisis dengan pendekatan yuridis normative melalui pendekatan perundang-undangan (statute approach), pendekatan konseptual (analytical and conceptual approach), pendekatan kasus (cases approach), dan pendekatan komparatif (comparative approach) dengan menggunakan penalaran deduktif dan/atau induktif guna mendapatkan dan menemukan kebenaran obyektif. Adapun teknik pengumpulan bahan dan data dilakukan dengan cara studi kepustakaan, terutama terhadap bahan yang ada hubungannya dengan obyek penulisan.

\section{Tinjauan Pustaka}

Pilihan berfikir yuridis dari salah satu teori tentang tujuan negara adalah Negara Kesejahteraan (Welfare State). Konsep negara hukum yang semula merupakan liberal berubah ke negara hukum yang menyelenggarakan kesejahteraan rakyat. ${ }^{14}$ Menurut konsep Negara Kesejahteraan, tujuan negara adalah untuk kesejahteraan umum. Negara dipandang hanya merupakan alat untuk mencapai tujuan bersama kemakmuran dan keadilan sosial bagi seluruh rakyat negara tersebut. ${ }^{15}$ Selain konsep negara berdasar atas hukum (biasa disebut negara hukum), juga dikenal konsep negara kesejahteraan (welfare state), yakni suatu konsep yang menempatkan peran negara dalam setiap aspek kehidupan rakyatnya demi terwujudnya kesejahteraan sosial bagi seluruh rakyat. ${ }^{16}$ Sehubungan dengan

menyalahgunakan kekuasaan untuk memuluskan aksi mereka. Pengungsi, perambah, dan masyarakat lokal hanyalah obyek yang dimanfaatkan oleh oknum ini dengan memanfaatkan kondisi mereka yang lemah secara ekonomi. Penegakan hukum perlu secara tegas diberikan kepada mereka bahkan perlu dipublikasikan kepada khalayak sebagaimana seorang koruptor yang jelas-jelas telah merugikan negara dan membohongi masyarakat. Wiratno, Pengelolaan Kawasan Taman Nasional Gunung Leuser, makalah disampaikan pada Shared Learning, Tangkahan: Pusat Informasi Lingkungan Indonesia bekerjasama dengan CIFOR, 22 Juni 2006. hal. 133.

${ }^{14}$ Kusnardi dan Bintan R. Saragih, "Ilmu Negara", (Jakarta: Gaya Media Pratama, 2000),

${ }^{15}$ CST Kansil dan Christine ST. Kansil, "Hukum Tata Negara Republik Indonesia (1)," (Jakarta: Rineka Cipta, 1997), hal. 20.

${ }^{16}$ Mustamin Dg. Matutu, Selayang Pandang (tentang) Perkembangan Tipe-Tipe Negara Modem, Pidato Lustrum ke IV Fakultas Hukum dan Pengetahuan Masyarakat Universitas Hasanuddin Ujung Pandang, 1972, hal. 15. 
konsep negara kesejahteraan tersebut, maka negara yang menganut konsep negara kesejahteraan dapat mengemban 4 (empat) fungsi ${ }^{17}$ yaitu:

1. The State as provider (negara sebagai pelayan);

2. The State as regulator (negara sebagai pengatur);

3. The State as enterpreneur (negara sebagai wirausaha); and

4. The State as umpire (negara sebagai wasit).

Merujuk pada fungsi negara yang menganut konsep negara kesejahteraan sebagaimana telah dikemukakan di atas, menyebabkan negara memegang peranan penting. Guna memenuhi fungsinya sebagai pelayan dan sebagai regulator, maka negara terlibat dan diberi kewenangan untuk membuat peraturan dalam pengelolaan sumberdaya hutan yang memberikan perlindungan kepada masyarakat lokal, sehingga terwujud kesejahteraan rakyat sebagaimana yang tercantum dalam Pembukaan UUD 1945 dan Pasal 33 ayat (3). Oleh sebab itu,peranan pemerintah dalam mendorong masyarakat agar lebih berdaya dalam ikut mengelola dan memanfaatkan sumber daya alam khususnya bidang kehutanan menjadi suatu hal yang sangat penting. Negara mempunyai peran penting dalam mengatur pengelolaan sumber daya hutan dalam mewujudkan hakhak masyarakat lokal. Instrumen penting yang dapat digunakan oleh negara dalam menyelenggarakan fungsi reguleren termasuk dalam bidang pengelolaan sumber daya hutan adalah undang-undang, dan ini merupakan aplikasi dari asas legalitas dalam konsep negara berdasar atas hukum.

Teori Negara Kesejahteraan sangat mendukung pengelolaan konflik pemanfaatan sumberdaya hutan dalam mewujudkan hak masyarakat lokal, sehingga akan mendukung terwujudnya kesejahteraan umum dan kemakmuran bagi seluruh rakyat Indonesia melalui sektor perpajakan.

Konsep Negara Kesejahteraan dalam UUD 1945 pertama kali diadopsi oleh Muhamad Hatta, ${ }^{18}$ yang dapat dikemukakan berdasarkan ketentuan Pasal 33 yang berbunyi:

(1) Perekonomian disusun sebagai usaha bersama berdasar atas asas kekeluargaan.

(2) Cabang-cabang produksi yang penting bagi negara dan yang menguasai hajat hidup orang banyak dikuasai oleh negara.

(3) Bumi dan air dan kekayaan alam yang terkandung di dalamnya dikuasai oleh negara dan dipergunakan untuk sebesar-besar kemakmuran rakyat.

(4) Perekonomian nasional diselenggarakan berdasar atas demokrasi ekonomi dengan prinsip kebersamaan, efisiensi, berkeadilan, berkelanjutan, berwawasan lingkungan,

\footnotetext{
${ }^{17}$ W. Friedmann., "The State and The Rule of Law In A Mixed Economy", (London: Steven \& Son, 1971), hal. 5.

${ }^{18}$ Jimly Asshiddiqie, "Undang-Undang Dasar 1945: Konstitusi Negara Kesejahteraan dan Realitas Masa Depan”, (Jakarta: Universitas Indonesia, 1998), hal. 44.
} 
kemandirian, serta dengan menjaga keseimbangan kemajuan dan kesatuan ekonomi nasional.

(5) Ketentuan lebih lanjut mengenai pelaksanaan Pasal ini diatur dalam Undang-Undang.

Kebijakan pengelolaan sumberdaya alam di Indonesia mengacu pada ideologi penguasaan dan pemanfaatan sumberdaya alam sebagaimana tercermin dalam Pasal 33 ayat (3) Undang-Undang Dasar 1945 yang berbunyi sebagai berikut:

\section{Bumi dan air dan kekayaan alam yang terkandung di dalamnya dikuasai oleh negara dan dipergunakan sebesar-besarnya untuk kemakmuran rakyatnya.}

Berdasarkan ketentuan tersebut dapat disimpulkan bahwa negara menguasai kekayaan alam yang terkandung di dalamnya, namun penguasaan ini terbatasi yaitu harus dipergunakan untuk sebesarnya-besarnya kemakmuran rakyat. ${ }^{19}$

Campur tangan Pemerintah tersebut di atas menunjukkan bahwa Indonesia menganut konsep negara kesejahteraan (Welfare State), sebagaimana dicetuskan oleh Beveridge. ${ }^{20}$ Selanjutnya, dalam perkembangannya karena keterlibatan pemerintah dalam melaksanakan fungsi-fungsinya dalam meregulasi dan mengawasi berbagai aktivitas di masyarakat, timbul berbagai permasalahan yang terjadi antara pemerintah dengan masyarakat di lapangan. Hal tersebut digambarkan oleh Tocqueville seringkali menimbulkan konflik terhadap sistem politik di suatu negara. Ia mengemukakan bahwa: "Conflict, however bounded; controversy, however regulated-these are features not incidental but essential to the operation of the political system". ${ }^{21}$

Tujuan hukum dapat dikaji melalui tiga sudut pandang, masing-masing:

Pertama, dari sudut pandang ilmu hukum positif normatif atau yuridis dogmatik, dimana tujuan hukum dititikberatkan pada segi kepastian hukumnya. Kedua, dari sudut pandang filsafat hukum, dimana tujuan hukum dititikberatkan pada segi keadilan. Ketiga, dari sudut pandang sosiologi hukum, tujuan hukum dititikberatkan pada segi kemanfaatannya. ${ }^{22}$

19 Muchsan, "Hukum Administrasi Negara dan Peradilan, Administrasi Negara di Indonesia", (Jakarta: Liberti, 2003), hal.9.

${ }^{20}$ Beveridge seorang anggota Parlemen Inggris dalam reportnya yang mengandung suatu program sosial, dengan perincian antara lain tentang meratakan pendapatan masyarakat, usulan kesejahteraan social, peluang kerja, pengawasan upah oleh Pemerintah dan usaha di bidang pendidikan. Muchtar Kusumaatmadja, Konsep-Konsep Hukum Dalam Pembangunan, (Bandung: PT. Alumni, 2002), hal.82.

${ }^{21}$ Tocqueville's seperti dikutip Gianfranco Poggi, "The Development of the Modern State", (New York: Stanford University Press, 1978), hal. 111.

${ }^{22}$ Achmad Ali, "Menguak Tabir Hukum, Suatu Kajian Filosofis dan Sosiologis", (Jakarta: PT. Gunung Agung, 2000), hal.72. 
Menurut ajaran utilitis dengan tujuan kemanfaatannya, yang dikemukakan oleh Jeremy Bentham. Menurut pandangan ini, tujuan hukum semata-mata adalah memberikan kemanfaatan atau kebahagiaan yang sebesar-besarnya bagi sebanyakbanyaknya warga masyarakat. Penangannya didasarkan pada filsafah sosial bahwa setiap warga masyarakat mencari kebahagiaan, dan hukum merupakan salah satu alatnya. Doktrin utilitis ini mennjurkan the greathes happiness principle' (prinsip kebahagiaan yang semaksimal mungkin). Tegasnya, menurut teori ini masyarakat yang ideal adalah masyarakat yang mencoba memperbesar kebahagiaan dan memperkecil ketidakbahagiaan atau masyarakat yang mencoba memberi kebahagiaan yang sebesar mungkin kepada rakyat pada umumnya dan agar ketidakbahagiaan diusahakan sedikit mungkin dirasakan oleh rakyat pada umumnya. ${ }^{23}$

Selain pandangan teori keadilan sebagaimana yang dikemukakan oleh Jeremy Bentham, dapat dikemukakan teori keadilan yang dikemukakan oleh John Rawls. Menurut John Rawls, semua teori keadilan merupakan teori tentang cara untuk menentukan kepentingan-kepentingan yang berbeda dari semua warga masyarakat. Menurut konsep teori keadilan utilitaris, cara yang adil mempersatukan kepentingan-kepentingan manusia yang berbeda adalah dengan selalu mencoba memperbesar kebahagiaan.

Menurut Rawls, bagaimanapun juga cara yang adil untuk mempersatukan berbagai kepentingan yang berbeda adalah melalui keseimbangan kepentingankepentingan tersebut tanpa memberikan perhatian istimewa terhadap kepentingan itu sendiri. Teori ini sering disebut 'justice as fairness '(keadilan sebagai kejujuran). Jadi yang pokok adalah prinsip keadilan mana yang paling fair, itulah yang harus dipedomani. Terdapat dua prinsip dasar keadilan. Prinsip yang pertama, disebut kebebasan yang menyatakan bahwa setiap orang berhak mempunyai kebebasan yang terbesar asal ia tidak menyakiti orang lain. Tegasnya, menurut prinsip kebebasan ini, setiap orang harus diberi kebebasan memilih menjadi pejabat kebebasan berbicara dan berfikir kebebasan memiliki kekayaan, kebebasan dari penangkapan tanpa alasan dan sebagainya. ${ }^{24}$

Prinsip keadilan yang kedua yang akan disetujui oleh semua orang yang fair adalah bahwa ketidaksamaan sosial dan ekonomi harus menolong seluruh masyarakat dan para pejabat tinggi harus terbuka bagi semuanya. Tegasnya, ketidaksamaan sosial dan ekonomi dianggap tidak adil kecuali jika ketidaksamaan ini menolong seluruh masyarakat. ${ }^{25}$

Teori keadilan ini sangat relevan untuk menjawab bagaimana seharusnya pengelolaan konflik pemanfaatan sumberdaya hutan dapat mewujudkan hak masyarakat lokal secara adil. Karena esensi hak masyarakat lokal dalam

${ }^{23}$ Ibid., hlm. 77 .

${ }^{24}$ Uzair Fauzan dan Heru Prasetyo, "Teori Keadilan Dasar-Dasar Filsafat Politik untuk Mewujudkan Kesejahteraan Sosial Dalam Negara", (yogyakarta: Pustaka Pelajar, 2006), hal. 181 dan 203.

${ }^{25}$ Ibid. 
pemanfaatan sumber daya hutan adalah adanya perlakuan yang adil untuk memanfaatkan dan mengelola sumber daya hutan secara arif bijaksana dan berkesinambungan untuk kepentingan masyarakat banyak dan kepentingan generasi yang akan datang.

Friedman mengemukakan bahwa suatu sistem hukum terdiri dari tiga unsur: ${ }^{26}$ hukum sebagai suatu sistem pada pokoknya mempunyai 3 (elemen), yaitu (a) struktur system hukum (structure of legal system) yang terdiri dari lembaga pembuat undang-undang (legislative), institusi pengadilan dengan strukturnya lembaga kejaksaan dan badan kepolisian negara, yang berfungsi sebagai aparat penegak hukum; (b) subtansi sistem hukum (substance of legal) yang berupa norma-norma hukum, peraturan-peraturan hukum, termasuk pola-pola perilaku masyarakat yang berada di balik sistem hukum; dan (c) budaya hukum masyarakat (legal culture) seperti nilai-nilai, ide-ide, harapan-harapan dan kepercayaankepercayaan yang terwujud dalam perilaku masyarakat dalam mempersepsikan hukum.

Pendapat serupa juga dikemukakan dalam teori hukum pembangunan dari Muchtar Kusumaatmadja. Berdasarkan kenyataan kemasyarakatan dan situasi kultural di Indonesia serta kebutuhan riil masyarakat Indonesia, Muchtar Kusumaatmadja merumuskan landasan atau kerangka teoritis bagi pembangunan hukum nasional dengan mengakomodasikan pandangan tentang hukum dari Eugen Ehrlich dan teori hukum Roscou Pound, dan mengolahnya menjadi suatu konsep hukum yang memandang hukum sebagai sarana pembaharuan, disamping sarana untuk menjamin ketertiban dan kepastian hukum. ${ }^{27}$

Untuk memberikan landasan teoritis dalam memerankan hukum sebagai sarana pembaharuan masyarakat serta membangun tatanan hukum nasional yang akan mampu menjalankan peranan tersebut, Muchtar Kusumaatmadja mengajukan konsepsi hukum yang tidak saja merupakan keseluruhan azas-azas dan kaidah-kaidah yang mengatur kehidupan manusia dalam masyarakat melainkan meliputi pula lembaga-lembaga (institutions) dan proses-proses yang mewujudkan berlakunya kaidah-kaidah itu dalam kenyataan. ${ }^{28}$

Dengan konsepsi hukum tersebut, tampak bahwa Muchtar memandang tatanan hukum itu sebagai suatu sistem yang tersusun atas 3 (tiga) komponen (sub sistem) yaitu: ${ }^{29}$

a. Azas-azas dan kaidah hukum;

b. Kelembagaan hukum;

c. Proses perwujudan hukum.

\footnotetext{
hal. 7.

${ }^{27}$ Ibid, hal. 7.

${ }^{28}$ Ibid.

${ }^{29}$ Ibid.
}

${ }^{26}$ Lawrence W Friedman, “American Law", (New York: W.W. Norton \& Company, 1984), 
Menurut Muchtar Kusumaatmadja, hukum merupakan sarana pembaharuan masyarakat didasarkan atas anggapan bahwa adanya keteraturan atau ketertiban dalam usaha pembangunan atau pembaharuan itu merupakan sesuatu yang diinginkan atau bahkan dipandang (mutlak) perlu. ${ }^{30}$

Anggapan lain yang terkandung dalam konsepsi hukum sebagai sarana pembangunan adalah bahwa hukum dalam arti kaidah atau peraturan hukum memang bias berfungsi sebagai alat (pengatur) atau sarana pembangunan dalam arti merupakan arah kegiatan rumusan kearah yang dikehendaki oleh pembangunan atau pembaharuan. ${ }^{31}$

Kedua fungsi tersebut diharapkan dapat dilakukan oleh hukum disamping fungsinya yang tradisional yakni untuk menjamin adanya kepastian dan ketertiban. $^{32}$

Perubahan maupun ketertiban atau keteraturan merupakan tujuan kembar dari masyarakat yang sedang membangun, hukum menjadi suatu alat (sarana) yang tidak dapat diabaikan dalam proses pembangunan. ${ }^{33}$

Peranan hukum dalam pembangunan dimaksudkan agar pembangunan tersebut dapat dicapai sesuai dengan yang telah ditetapkan. Hal ini berarti bahwa diperlukan seperangkat produk hukum baik berwujud perundang-undangan maupun keputusan badan-badan peradilan yang mampu menunjang pembangunan. ${ }^{34}$

Dalam pelaksanaan ideologi penguasaan dan pemanfaatan sumberdaya alam tersebut di atas dijabarkan lebih lanjut dalam peraturan perundang-perundangan antara lain mengenai sumberdaya alam hayati dan ekosistemnya. Materi muatan ideologi tersebut di atas yang dapat dicermati implikasinya pada kinerja Pemerintah Pusat khususnya Departemen Kehutanan beserta unit pelaksana teknis dalam hal ini Balai taman Nasional dan Pemerintah Daerah yang diberi kewenangan untuk mengelola kawasan pelestarian alam masyarakat sekitar kawasan.

Dalam kaitannya dengan pengurusan hutan perlu adanya good forestry governance. $^{35}$ Adapun syarat good forestry governance antara lain: Pertama, adanya transparansi hukum, kebijakan dan pelaksanaan; Kedua, tersedianya mekanisme yang "legitimate" dalam proses akuntabilitas publik; Ketiga, adanya mekanisme perencanaan, pelaksanaan dan monitoring serta evaluasi yang

${ }^{30}$ Muchtar Kusumaatmadja, "Konsep-Konsep Hukum Dalam Pembangunan”, (Bandung: PT. Alumni, 2002), hal. 89.

${ }^{31}$ Ibid.

${ }^{32}$ Ibid.

${ }^{33}$ Ibid, hal. 89.

${ }^{34}$ Otje Salman dan Anthon F. Susanto, "Beberapa Aspek Sosiologi Hukum", (Bandung: PT. Alumni, 2004), hal. 65.

${ }^{35}$ Elfian Efendi, "Jangan Menunggu Kapal Pecah", (Jakarta: Lembaga Penerbit Fakultas Ekonomi Universitas Indonesia, 2001), hal. 61. 
partisipatif; Keempat, adanya mekanisme demokratis dalam memperkuat daerah; Kelima, memperbaiki birokrasi pusat yang tidak efektif dan efisien untuk perbaikan kinerja melalui pengembangan institusi yang mengarah kepada peningkatan pelayanan publik. ${ }^{36}$ Beberapa prasyarat di atas sudah sejalan dengan subtansi Undang-Undang No.28 Tahun 1999 tentang Penyelenggaraan Negara yang Bersih dan Bebas dari KKN. ${ }^{37}$

Pengelolaan sumberdaya hutan adalah sistem pengelolaan hutan dalam rangka memberikan perlindungan sistem penyangga kehidupan baik hutan yang berada di kawasan taman nasional maupun hutan produksi, namun dalam penelitian ini digunakan khusus untuk lingkup pengelolaan hutan di kawasan taman nasional. Apabila pengelolan konflik pemanfaatan sumber daya hutan dapat menerapkan prinsip keadilan, maka akan dapat meningkatkan perekonomian masyarakat. Artinya hak-hak masyarakat lokal dapat dipenuhi dengan sebaikbaiknya, sehingga cita-cita konsep Negara kesejahteraan dapat terwujud. Sehingga diharapkan penelitian ini dapat memberikan kontribusi yang signifikan dalam pengelolaan sumber daya hutan dan bagaimana mewujudkan hak masyarakat lokal, terutama perlindungan dalam bentuk perbaikan atas pengaturan perundangundangan pada masa yang akan datang.

\section{Tumpang Tindih dan Konflik Kewenangan dalam Pengelolaan Sumber Daya Hutan}

Sejak implementasi otonomi daerah berdasarkan UU No.32 Tahun 2004 tentang Pemerintahan Daerah, persoalan utama yang dihadapi dalam pengembangan konservasi di Indonesia adalah pembagian kewenangan pusat dan daerah. Berdasarkan peraturan perundangan yang berlaku, kewenangan konservasi masih ada di tangan pemerintah pusat, padahal ada banyak inisiatif di tingkat daerah mengenai peraturan pengelolaan kawasan konservasi yang belum terakomodir oleh pemerintah pusat.

Potensi peranan daerah perlu dipahami, karena secara defakto kawasankawasan yang ditetapkan dengan fungsi konservasi (dan juga fungsi lainnya seperti produksi dan lindung) berada di wilayah administratif daerah. Orang ditingkat daerah sangat memahami kondisi aktual dan kebutuhan bagi pengelolaan yang terbaik. Di samping itu, karena kawasan konservasi di masa lalu seringkali tidak disertai dengan data dan informasi yang memadai. Dalam kondisi tanpa kewenangan, maka mengkomunikasikan kepentingan konservasi keanekaragaman hayati dengan kepentingan kehidupan masyarakat di dalam dan di luar kawasan menjadi sulit dilaksanakan oleh daerah. ${ }^{38}$

$$
{ }^{36} \text { Ibid., hal. } 61 .
$$

${ }^{37}$ Pasal 3 Undang-Undang No.28 Tahun 1999, menyebutkan bahwa ada tujuan asas umum penyelenggaraan negara, yaitu: Kesatu, kepastian hukum, Kedua, asas tertib penyelenggara negara, Ketiga, asas kepentingan umum, Keempat, asas keterbukaan. 
Konservasi sumber daya alam hayati dalam Undang-Undang Nomor 5 tahun 1990 adalah pengelolaan sumber daya alam hayati yang pemanfaatannya dilakukan secara bijaksana untuk menjamin kesinambungan persediannya dengan tetap memelihara dan meningkatkan kualitas keanekaragaman dan nilainya. Tujuannya untuk mengusahakan terwujudnya kelestarian sumber daya alam hayati serta keseimbangan ekosistemnya sehingga dapat lebih mendukung upaya peningkatan kesejahteraan masyarakat dan mutu kehidupan manusia. ${ }^{39}$

Dalam Undang-Undang Nomor 41 Tahun 1999 Tentang Kehutanan, disebutkan bahwa peraturan konservasi masih merupakan kewenangan pemerintah pusat. Peraturan ini menunjukkan secara jelas bahwa belum terjadi desentralisasi di bidang konservasi, padahal banyak inisiatif di tingkat kabupaten dan masyarakat yang dapat melengkapi peraturan konservasi tersebut. Pengelolaan sentralistik diperparah oleh proses perencanaan, penataan kawasan, perlindungan dan pengawasan dan berbagai kegiatan lainnya yang berkaitan dengan pengelolaan kawasan konvensi yang seringkali dikembangkan secara tidak transparan oleh pemerintah pusat. Dukungan pemerintah daerah dan masyarakat terhadap pengelolaan konservasi sangat rendah. ${ }^{40}$

Konservasi dalam perspektif Undang-Undang Konservasi Nomor 5 Tahun 1990 dijabarkan dengan berbagai bentuk pengelolaan kawasan yang mencakup Kawasan Suaka Alam (Cagar Alam dan Suaka Margasatwa), Cagar Biosfer dan Kawasan Pelestarian Alam (Taman Nasional, Taman Hutan Raya dan Taman Wisata Alam). Dalam pengelolaan ketiga bentuk kawasan ini sama sekali tidak dicantumkan bentuk pengelolaan yang dilakukan oleh pemerintah daerah dan masyarakat yang berada di sekitar kawasan tersebut. Masyarakat hanya dilibatkan sebagai peserta untuk diberi pendidikan dan penyuluhan mengenai konservasi.

Konsep pengelolaan bersama dengan masyarakat dan pihak pemerintah daerah sebenarnya telah dicoba di beberapa Taman Nasional yang ada di Indonesia. Taman Nasional Kayan Mentarang, Kalimantan Timur misalnya, telah mengembangkan manajemen kolaboratif dengan melibatkan pihak kabupaten dan masyarakat setempat untuk pengelolaan bersama lewat Forum Musyawarah Masyarakat Adat.

Merujuk perspektif yang termuat dalam peraturan tersebut, ada beberapa hal ditingkat daerah dan masyarakat yang perlu dicermati, terutama bagi pemerintah pusat untuk meninjau kembali peraturan yang ada. Masalah tersebut antara lain:

Pertama, masyarakat sekitar kawasan konservasi masih kurang dilibatkan dalam pengelolaan bersama kawasan konservasi. Bahkan dianggap sebagai musuh yang selalu merambah kawasan. Oleh karenanya adanya asumsi harus diberi pendidikan dan penyuluhan mengenai konservasi.

${ }^{38}$ Ciriacy Wantrup, Common Property as A Concept in Natural resources Policy, Natural Resources Journal, 1975, hal. 713-737.

${ }^{39}$ Dixon, J.A dan Paul B. Sherman, "Economic of Protected Areas: A New Look at Benefit and Cost", (London: East-West Center, 1990), hal. 15-16.

${ }^{40}$ Ibid. 
Kedua, pola insentif yang dikembangkan untuk pengelolaan bersama tidak jelas arah dan tujuannya. Pemerintah hanya berharap masyarakat dapat membantu memelihara kawasan saja tanpa adanya perjanjian yang jelas. Jika terjadi masalah terkait dengan kawasan tersebut, masyarakat merasa tidak bertanggungjawab atas permasalahan yang dihadapi.

Ketiga, Di lapangan telah terjadi tumpang tindih peraturan pusat dengan daerah, terutama dalam masa desentralisasi ini. Permasalahan yang timbul terkait dengan pengelolaan kawasan, tata ruang wilayah dan pemanfaatan lahan. Pemerintah daerah setempat dengan semangat desentralisasi merasa memiliki untuk mengelola dan memanfaatkan kawasan tersebut untuk kesejahteraan rakyatnya.

Keempat, pandangan bahwa belum adanya contoh kegiatan konservasi yang dapat memberikan andil nyata kepada pemerintah daerah setempat dan masyarakat dalam bentuk Pendapatan Asli Daerah (PAD). Berkaitan dengan hal ini, perlu dijelaskan adnya beberapa kegiatan konservasi yang dapat memberikan sumbangan kepada pemerintah daerah dan masyarakat setempat seperti ekowisata, penelitian berdampak bagi masyarakat, dan kegiatan sejenis lainnya.

Keempat permasalahan tersebut di atas mulai berkembang secara intensif setelah era otonomi daerah. Ironisnya, perkembangan isu ini tidak diimbangi dengan kemauan daerah untuk meningkatkan kegiatan konservasi, tetapi karena mau meningkatkan perkembangan daerahnya dengan memanfaatkan sumberdaya alam secara maksimal. Permasalahan yang muncul di tingkat daerah berkaitan dengan kawasan konservasi yang masih dikelola oleh pusat antara lain: Taman Nasional, Cagar Alam, Hutan Wisata dalam era otonomi ini semakin meluas dan parah terkait dengan pembagian kewenangan tersebut. Munculnya kepentingan yang berbeda antara pemerintah pusat, pemerintah daerah dan masyarakat menimbulkan konflik yang berkepanjangan.

Di satu sisi pemerintah pusat lebih mempertahankan kawasan konservasi sesuai dengan pembentukannya, sedangkan pihak daerah dengan konsep "pembangunan" untuk meningkatkan kesejahteraan masyarakat dan PAD berusaha untuk melepaskan kawasan tersebut dari kawasan hutan negara. Sementara itu masyarakat yang berada di sekitar kawasan merasa berhak untuk dapat menikmati hasil dari kawasan tersebut dalam masa desentralisasi.

Adanya pengakuan secara hukum di Tingkat Pemerintah Daerah atas upayaupaya yang dilakukan oleh masyarakat dalam mendukung kegiatan konservasi, menunjukkan adanya kebijakan daerah untuk membantu masyarakat dalam pelaksanaan kegiatan konservasi. Kebijakan tersebut seharusnya didukung dan ditegakkan oleh Departemen Kehutanan yang dapat memberikan masukan konsep-konsep pengelolaan hutan secara nasional yang selanjutnya dijabarkan oleh pihak daerah sebagai pedoman pelaksanaan di lapangan.

Departemen Kehutanan dan pemerintah daerah sebenarnya memiliki konsep konservasi dasar yang sama, yaitu memberikan perlindungan dan pengawetan terhadap keanekaragaman hayati dan ekosistemnya. Dari aspek pemanfaatan Departemen Kehutanan memberikan zona pemanfaatan dalam kawasan konservasi bagi masyarakat secara terbatas. Sedangkan pemerintah daerah 
memberikan kewenangan penuh kepada masyarakat untuk mengembangkan kawasan konservasi lokal dengan berbagai model pengelolaan dan peruntukannya.

Dari aspek pendekatan kebijakan, Departemen Kehutanan cenderung bertindak secara 'top down' tanpa memperhatikan kebutuhan yang diperlukan di lapangan. Pendekatan ini mengakibatkan munculnya permasalahan di kawasan konservasi, baik dengan pemerintah setempat maupun masyarakat, antara lain konflik pemanfaatan kawasan baik dengan masyarakat maupun pemerintah daerah setempat. Sementara pemerintah daerah berusaha mengembangkan konsep 'bottom up' yang memberikan kewenangan kepada masyarakat untuk mengelola kawasan konservasi lokal, yang kemungkinan terpaksa mengakomodir masyarakat dengan peraturan yang dibuatnya.

Undang-Undang Nomor 22 tahun 1999 yang telah direvisi dengan UndangUndang Nomor 32 tahun 2004 Tentang Pemerintahan Daerah, menjadi dasar bagi daerah untuk mengelola otonom kehutanan di tingkat daerah. Dinas Kehutanan baik propinsi maupun kabupaten dan kota dapat berperan aktif untuk bekerjasama dengan pihak-pihak terkait di pusat, daerah dan masyarakat. Pemerintah daerah dapat mengeluarkan peraturan yang mendukung kegiatan-kegiatan konservasi yang dilakukan oleh masyarakat dengan mengacu pada kebijakan pusat. Demikian juga dapat menjabarkan kebijakan sesuai dengan kebutuhan daerah yang diperlukan dalam hal ini kebijakan konservasi. Adanya pembagian peran tersebut, maka upaya penyelesaian konflik yang terjadi selama ini dapat teratasi.

Berkaitan dengan permasalahan pembagian peran dan koordinasi yang menjadi kendala utama yang dihadapi oleh Departemen Kehutanan, Pemerintah daerah dan masyarakat dalam kegiatan konservasi, diperlukan suatu mekanisme yang dapat membantu menyelesaikan masalah tersebut. Salah satu mekanisme yang dapat diginakan oleh Departemen Kehutanan maupun oleh pemerintah daerah adalah mekanisme konsul;tasi publik yaitu suatu rangkaian proses yang dijalankan oleh pemerintah atau pihak-pihak lain yang berkepentingan sebagai lembaga internasional, lembaga swadaya masyarakat, kelangan perguruan tinggi, masyarakat dan pihak lain yang memiliki inisiatif yang sama dalam pembuatan kebijakan kepada masyarakat khususnya dalam pengelolaan konservasi.

Sejak era otonomi daerah mulai bergulir, persoalan yang dihadapi dalam pengembangan kawasan konservasi di Indonesia adalah pembagian kewenangan dan koordinasi antara pemerintah pusat dan daerah. Pada akhir tahun 80-an dan sepanjang dekade tahun 90-an, gerakan rakyat di tingkat lokal yang melawan ketidak-adilan dalam pelaksanaan pembangunan meningkat tajam. Kasus yang mencuat bervariasi dari kasus individual, keluarga, sampai yang melibatkan sebuah komunitas lokal, baik itu berbentuk suku, kampung maupun beberapa kampung sekaligus. ${ }^{41}$ Seiring dengan itu, menjamur pula organisasi-organisasi

${ }^{41}$ Data kasus konflik agraria yang dikeluarkan oleh KPA yang merekam sengketa agraria di Indonesia sejak 1953 sampai dengan 2000, berjumlah 1455 kasus, melibatkan 242.088 Keluarga, 533.866 jiwa dan lahan seluas 1.456 .773 hektar yang merupakan lahan masyarakat adat dan lokal. Lawan masyarakat dalam seluruh konflik ini adalah Pemerintah, Perusahaan negara, dan Perusahaan Swasta. Ini menunjukkan bahwa konflik agraria di Indonesia antara masyarakat adat dan lokal dengan Pemerintah dan para pemilik modal adalah konflik struktural akibat pengambil- 
non-pemerintah ${ }^{42}$ yang melakukan advokasi "pembelaan"43 hak-hak rakyat dan penyelamatan lingkungan. Dan dengan itu merebak pula isu yang dibawa dalam kasus-kasus itu. Pelanggaran HAM, kerusakan lingkungan, otonomi daerah dan desa, dan kebijakan-kebijakan negara.

Otonomi yang mencakup kontrol atas wilayah adat dan sumberdaya agraria, self-governance dan ekspresi hak-hak sosial budaya merupakan substansi yang tak terpisahkan meskipun dapat dibedakan. Dinamika internal dari ketiga faktor ini dan interaksi dengan pihak lain melahirkan apa yang disebut identitas sebagai sebuah proses. Menguraikan ketiga hal itu sebagai bagian sendiri-sendiri hanya akan melahirkan paham identitas sebagai sesuatu yang terberi dan rigid. Pemahaman seperti ini bermuara pada dikotomi "kita" "mereka" yang potensial konflik. Sementara melihat ketiga faktor itu sebagai sebuah makna "tritunggal" akan melahirkan sebuah masyarakat yang siap bertransformasi dalam proses.

Transformasi yang bagaimana kiranya tak perlu diragukan lagi, yakni merengkuh cita-cita pembebasan. Pembebasan yang berarti merebut otonomi yang ditandai oleh otonomi dalam ketiga faktor tersebut: keleluasaan untuk mengurus diri sendiri, hak atas tanah dan sumberdaya agraria dalam wilayah yang diklaim sebagai ruang hidup mereka dan kemeredekaan (bukan kebebasan) mengekspresikan hak-hak sosial budaya. Dan jika ini yang menjadi makna dari isu gerakan indigenous peoples dan sejauh ini dapat dibaca demikian, maka secara substansial ada persambungan yang sangat kuat antara kedua terminologi itu.

Dengan demikian masyarakat adat semestinya dipahami sebagai sebuah kategori politis yang ditentukan oleh rangkaitan terpadu (integral) masa lalu, kekinian dan tujuan atau cita-cita politiknya dan model-model perjuangannya.

Kedua, identitas yang dipahami dengan baik dalam lingkup masyarakat adat maupun oleh pihak di luar masyarakat adat adalah landasan utama dalam mengusung cita-cita pembebasan yang disebutkan di atas: Kedaulatan mengurus diri sendiri atau secara lebih berkerangka disebutkan sebagai "otonomi komunitas masyarakat adat" yang dicirikan oleh self-governance, hak atas tanah dan sumberdaya agraria, dan hak-hak sosial budaya.

Keleluasaan untuk mengurus diri sendiri (self-governance) adalah sebuah "warisan sejarah politik" dalam komunitas-komunitas masyarakat adat. Disebut warisan politik karena sistem pengurusan diri sendiri itu lahir dan bertumbuh dari

alihan hak masyarakat oleh negara untuk para pemilik modal. Sampai tingkat tertentu dapat disaksikan dalam data tersebut bahwa aparat negara selalu menjadi pihak yang diperhadapkan dengan masyarakat. Dalam seluruh kasus ini pandangan bahwa Negara adalah alat bagi kapitalisme untuk menguasai sumberdaya agraria di dunia mendapat pembenaran yang signifikan, baik dari aspek legislasinya maupun dalam operasionalisasi peraturan perundangannya.

${ }^{42}$ Dapat dilihat dalam "Prosiding Seminar SMERU; Wawasan Tentang LSM Indonesia: Sejarah, Perkembangan Serta Prospeknya"; 15 Agustus 2000. Dalam uraian tentang perkembangan LSM di Aceh sebagai salah satu daerah yang dikaji, tampak bahwa dalam era 70 -an baru ada beberapa LSM di Aceh. Dalam era 80 -an berkembang menjadi belasan dan dalam 90 -an telah ada puluhan LSM di Aceh. Perkembangan ini berjalan melalui proses "membelah diri", sebuah istilah yang diambil dari khasanah biologi tentang pembelahan sel atau organisma mikro.

${ }^{43}$ James Petras dan Henry Veltmeyer, "Globalization Unmasked: Imperialism in the $21^{\text {st }}$ Century”, dalam edisi terjemahan, (Jakarta: Kreasi Wacana, 2002), hal. 235-257. 
sebuah proses internal dan interaksi yang lama dengan lingkungan dan komunitas masyarakat sekitar. Dalam beberapa contoh yang disebutkan di atas dapat ditemukan apa yang disebut sebagai hukum adat, lembaga adat dengan strukturnya masing-masing dan wilayah adat. Dan di atas itu ada orang-orang anggota komunitas tersebut yang mengidentifikasi diri sebagai bagian dari komunitas itu. Dengan adanya wilayah, hukum dan lembaga serta masyarakatnya sendiri, maka bukan sebuah keanehan bahwa mereka kemudian harus memiliki sistem pengurusan diri sendiri.

Otonomi itulah yang membentuk mereka menjadi sebuah entitas politik dengan hak-hak yang melekat atau bawaan dan bukan hak-hak berian. Dalam sistem penyelenggaraan Negara Indonesia selama ini, terjadi perampasan atau pengambil-alihan hak-hak itu. Pengambilalihan hak bawaan ini kemudian dipolitisir menjadi pengaturan hak-hak berian oleh negara. Inilah sejarah kelam komunitas-komunitas masyarakat adat ketika diberlakukannya Undang-undang Pemerintahan Desa No. 5 Tahun 1979. Celakanya, setelah UU ini dicabut dan tidak diberlakukan lagi dengan dikeluarkannya UU No. 22/1999 dan kemudian UU No. 32/2004 tentang Pemerintahan Daerah, paradigma hak bawaan dan hak berian terhadap komunitas masyarakat adat tidak berubah. Masih tetap dengan paradigma lama, yaitu mencerabut hak bawaan masyarakat adat dan lokal, kemudian diperlakukan sebagai hak berian negara. Ini jelas terlihat dalam konsep hak atas tanah.

Hak atas tanah dan sumberdaya agraria lainnya sesungguhnya telah cukup jelas arahnya dalam TAP MPR No. IX/2001 tentang Pembaruan Agraria dan Pengelolaan Sumberdaya agraria. Pasal 6 ayat 1 butir a TAP ini menyatakan bahwa arah kebijakan pembaruan agraria antara lain adalah: ${ }^{44}$

\section{Ayat 1 butir a:}

Melakukan pengkajian ulang terhadap berbagai peraturan perundang-undangan yang berkaitan dengan agraria dalam rangka sinkronisasi kebijakan antarsektor demi terwujudnya peraturan perundang-undangan yang didasarkan pada prinsip-prinsip sebagaimana dimaksud Pasal 5 Ketetapan ini;

Ayat 1 butir b:

Melakukan pengkajian ulang terhadap berbagai peraturan perundang-undangan yang berkaitan dengan agraria dalam rangka sinkronisasi kebijakan antarsektor demi terwujudnya peraturan perundang-undangan yang didasarkan pada prinsip-prinsip sebagaimana dimaksud Pasal 5 Ketetapan ini"

Ayat 1 butir d:

${ }^{44}$ Pasal 6 TAP MPR No. IX/2001 tentang Pembaharuan Agraria dan Pengelolaan Sumber Daya Agraria. 
Menyelesaikan konflik-konflik yang berkenaan dengan sumberdaya agraria yang timbul selama ini sekaligus dapat mengantisipasi potensi konflik dimasa mendatang guna menjamin terlaksananya penegakan hukum dengan didasarkan atas prinsip-prinsip sebagaimana dimaksud Pasal 5 Ketetapan ini. adalah: ${ }^{45}$

Sementara arah kebijakan dalam pengelolaan sumberdaya agraria antara lain

Ayat 2 butir c

Melakukan pengkajian ulang terhadap berbagai peraturan perundang-undangan yang berkaitan dengan pengelolaan sumberdaya agraria dalam rangka sinkronisasi kebijakan antarsektor yang berdasarkan prinsip-prinsip sebagaimana dimaksud Pasal 5 Ketetapan ini"

Aayat 2 butir a:

Memperluas pemberian akses informasi kepada masyarakat mengenai potensi sumberdaya agraria di daerahnya dan mendorong terwujudnya tanggung jawab sosial untuk menggunakan teknologi ramah lingkungan termasuk teknologi tradisional: dan

Ayat 2 butir e:

Menyelesaikan konflik-konflik pemanfaatan sumberdaya agraria yang timbul selama ini sekaligus dapat mengantisipasi potensi konflik di masa mendatang guna menjamin terlaksananya penegakan hukum dengan didasarkan atas prinsip-prinsip sebagaimana dimaksud Pasal 5 Ketetapan ini.

Meskipun arah reformasi agraria dan pengelolaan sumberdaya agraria sudah cukup jelas dalam TAP tersebut, namun dalam pelaksanaannya konsistensi pemerintah dalam mewujudkan amanat TAP tersebut masih sangat lemah. Bahkan dapat dikatakan tidak ada kemauan politik pemerintah untuk melaksanakannya. Hal ini dapat dibuktikan dengan adalah sejumlah kebijakan politik yang lahir setelah ditetapkannya TAP No. IX/2001 tersebut. UU No. 19/2004 yang memberikan ijin bagi pertambangan di hutan lindung; Perpres 36/2005 tentang pengadaan tanah bagi pembangunan untuk kepentingan umum yang telah direvisi namun tidak meninggalkan roh eksploitasi hak rakyat banyak dalam Perpres No. 65/2006. Pasal 13 Perpres 65 ini misalnya, menyatakan bahwa ganti rugi yang diberikan bisa berupa uang, tanah pengganti, pemukiman kembali dan atau

\footnotetext{
${ }^{45}$ Ibid., Pasal 5.
} 
gabungan dari itu atau bentuk ganti rugi yang lain. Kedua peraturan perundangan ini dibuat dalam dua tahun terakhir, yang berarti setelah penetapan TAP IX/2001.

Inkonsistensi ini dengan mudah dapat terjadi di Indonesia, karena pada tataran konstitusi masih terdapat pengakuan bersyarat terhadap masyarakat adat, sebagaimana dapat dilihat dalam Pasal 18 B dan Pasal 28 I Amandemen II UUD 1945, di mana persyarakatan sepanjang masih ada, sesuai dengan perkembangan masyarakat, tidak bertentangan dengan prinsip negara kesatuan Republik Indonesia dan diatur dengan undang-undang telah membuka ruang manipulasi politik hukum terhadap masyarakat adat. Tidak mengherankan jika kita kemudian melihat kondisionalitas yang sama dalam UUPA 1960 dan bahkan yang lebih buruk lagi adalah UU No. 41/1999 tentang Kehutanan, UU No. 7/2004 tentang Sumberdaya Air, UU Pertambangan dan berbagai peraturan organik, termasuk Perpres 36/2005 dan Perpres No. 65/2006 yang telah disebutkan di atas.

Pengelolaan hutan secara umum dan khusus dalam rangka pengelolaan keanekaragaman hayati hutan di Indonesia berlandaskan pada berbagai kebijakan mulai dari UUD 1945, Undang-Undang, Peraturan Pemerintah, Keputusan Presiden, Keputusan Menteri dan Keputusan/Surat Edaran Direktur Jenderal. Kebijakan pemerintah yang telah dibuat merupakan landasan bagi seluruh stakeholder (aparat pemerintah, pengusaha, LSM, masyarakat akademis dan umum) dalam melaksanakan pengelolaan hutan dan keanekaragaman hayati di dalamnya secara berkelanjutan.

Berbagai ancaman terhadap kelestarian hutan dan keanekaragaman hayati di dalamnya semakin meningkat, baik kualitas maupun kuantitasnya. Hal ini dapat terjadi karena hal-hal sebagai berikut:

Pertama, Dualisme kebijakan pemerintah antara mengkonservasi dan mengeksploitasi sumberdaya hutan baik inter maupun antar departemen, sering mengakibatkan upaya konservasi sering dikalahkan oleh upaya eksploitasi.

Kedua, Kuatnya egosektoral (inter dan antar sektoral) telah mengakibatkan banyak kawasan hutan (produksi dan konservasi) yang harus berubah fungsi untuk kegiatan pembangungan di sektor lain, contoh kasus antara Departemen Kehutanan dengan Departemen Pertambangan kaitannya dengan pemanfaatan kawasan konservasi yang terdapat bahan tambang potensial di dalamnya. Pertimbangan atas nilai ekonomi bahan tambang dan ketidakmampuan mengungkapkan nilai ekonomi kawasan konservasi, akan menjadi ancaman bagi keutuhan kawasan-kawasan konservasi yang di dalamnya terdapat bahan tambang yang potensial.

Ketiga, Kebijakan dalam penentuan kawasan sebagai hutan produksi, hutan konservasi dan hutan lindung lebih mendasarkan pada kondisi lahan (jenis tanah, kelerengan, curah hujan) dan tidak mendasarkan pada potensi dan kepentingan keanekaragaman hayatinya, sehingga hutan dataran rendah yang memiliki kekayaan keanekaragaman paling tinggi justru dialokasikan sebagai hutan produksi, bahkan dialokasikan untuk dikonversi bagi pembangunan sektor lain (perkebunan, transmigrasi.

Keempat, Kebijakan pengelolaan hutan yang mengakibatkan tertutupnya akses masyarakat lokal terhadap kawasan hutan (produksi dan konservasi), telah mengakibatkan konflik yang berkepanjangan dengan masyarakat lokal. 
Kelima, Pengalihan kewenangan pengelolaan hutan kepada daerah ternyata telah mengakibatkan semakin maraknya eksploitasi hutan yang tidak lagi mengindahkan aspek-aspek kelestarian. Hal ini dapat terjadi karena kesadaran para pejabat pemerintah daerah untuk mengkonservasi keanekaragaman hayati dan melestarikan sumberdaya hutan masih rendah. Keinginan untuk memperoleh Pendapatan Asli Daerah (PAD) secara mudah dan cepat telah mengkibatkan meningkatnya eksploitasi hutan (seperti terjadi di Riau dan Kalimantan Timur), tanpa mengindahkan aspek kelestarian.

Keenam, Kebijakan pemerintah dalam memberikan ijin industri kayu yang ijin ini diberikan bukan oleh Departemen Kehutanan telah mengakibatkan permintaan kayu nasional lebih besar dari pada pasokan legal (Hak Pengusahaan Hutan, Hutan Tanaman Industri, Izin Pengelolaan Kawasan) sehingga marak terjadi pencurian kayu (pasokan kayu ilegal ) untuk memenuhi kebutuhan kayu nasional tersebut.

Ketujuh, Keberpihakan pemerintah kepada konglomerat (pengusaha) dalam pengelolaan hutan telah menimbulkan 'dendam dan sakit hati' bagi masyarakat lokal yang merasa juga berhak memiliki hutan, sehingga setelah reformasi bergulir, sebagian masyarakat lokal berlomba untuk memperoleh haknya kembali dengan memanen hasil hutan sesuai dengan kebutuhan mereka. Selama ini masyarakat hanya diperlakukan sebagai penonton terhadap eksploitasi hutan di daerahnya, yang telah memberikan kekayaan yang sangat besar bagi pengusaha.

Kedelapan, Tidak terjaminnya kepastian usaha dalam pengusahaan hutan (bagi HPH) mengakibatkan terjadinya eksploitasi habis-habisan (over eksploitasi) oleh para pengusaha HPH untuk memperoleh keuntungan sebanyak-banyaknya dalam waktu singkat dan untuk mengimbangi (membayar) pungutan-pungutan baik yang sifatnya resmi maupun tidak resmi.

Kesembilan, Kayu hutan tidak ditetapkan sebagai asset tetap dalam pengusahaan hutan sehingga untuk memperoleh keuntungan maksimal maka HPH mengekploitasi hutan habis-habisan.

Kesepuluh, Kebijakan yang dikeluarkan pemerintah dalam menilai kinerja sebuah HPH tidak berdasarkan pada kondisi hutan paska eksploitasi tidak berdasar pada kelestarian hutan tetapi lebih kepada akuntansi kehutanan. Kinerja dikatakan baik jika akuntabilitasnya tinggi. Untuk memperoleh akuntabilitas yang tinggi maka HPH akan cenderung untuk memperbesar eksploitasi.

Disamping kesepuluh kebijakan yang menyebabkan adanya tumpang tindih kewenangan dalam pengelolaan sumber daya hutan, masih terdapat beberapa faktor yang menyebabkan adanya masalah tumpang tindih tersebut.

Pertama, Penggabungan banyak HPH yang kinerjanya buruk di luar Jawa dengan PT. INHUTANI (I sampai V) semakin memperparah kerusakan hutan yang terjadi karena pada kenyataannya di lapangan mereka juga (para pemegang $\mathrm{HPH}$ ) yang masih melaksanakan eksploitasi ditambah beban harus berbagi hasil dengan PT. INHUTANI.

Kedua, Kegiatan AMDAL, kebijakan yang mewajibkan HPH melaksanakan perlindungan terhadap flora fauna (terutama yang dilindungi), pengalokasian dan pengelolaan Kawasan Pelestarian Plasma Nutfah, pada kenyataannya masih bersifat formalitas, implementasi dan monitoringnya di lapangan masih sangat 
kurang. Sanksi dan penegakan hukum bagi HPH yang melanggar ketentuan ini juga masih lemah. Hal ini mengakibatkan HPH tidak peduli terhadap keberadaan satwa dan tumbuhan yang dilindungi yang berada di dalam areal konsesinya.

Ketiga, Kawasan konservasi di Indonesia sangat luas dan tersebar di seluruh wilayah Indonesia, yang selama ini dikelola secara sentralistik, mempunyaii banyak kelemahan terutama dalam perlindungan dan pengamanannya. Keterbatasan sumberdaya manusia, dana, prasarana dan sarana yang lainnya, mengakibatkan tidak kemampuannya dalam menanggulangi gangguan terhadap kawasan maupun perburuan liar.

Keempat, Konservasi keanekaragaman hayati dan ekosistemnya yang dilaksanakan selama ini masih cenderung kepada perlindungan dan pengawetan, belum mengarah kepada aspek pemanfaatan sehingga konservasi masih dianggap sebagai kegiatan yang memerlukan banyak dana sehingga sering dikalahkan oleh pertimbangan-pertimbangan ekonomis pemanfaatannya untuk kepentingan lain.

Kelima, Masih sangat kurangnya penilaian ekonomi terhadap kawasan konservasi secara integrated telah mengakibatkan kawasan ini sering dikalahkan oleh kepentingan lain (oleh sektor) lain yang merasa mempunyai nilai ekonomis lebih tinggi.

Keenam, Euforia reformasi bagi sebagian masyarakat lokal yang tadinya aksesnya terhadap sumberdaya hutan tertutup, telah mengakibatkan masyarakat merasa punya hak dan bebas memanen hasil hutan sesuai dengan keinginan mereka.

Ketujuh, Masih lemahnya penegakan hukum bagi para perambah kawasan hutan (konservasi, produksi dan hutan lindung), mengakibatkan perambahan hutan cenderung terus meningkat.

Kedelapan, Pengawasan peredaran satwa dan tumbuhan juga masih lemah. Selain itu adanya kesulitan untuk menelusuri asal tumbuhan dan satwa yang diperdagangkan apakah berasal dari hasil penangkaran atau tangkapan alam (perburuan liar).

Kegiatan sektor-sektor lainnya seperti Departemen Pertambangan, Transmigrasi dan Pekerjaan Umum telah menyebabkan dampak terhadap keanekaragaman hayati yang harus dipertimbangkan. BAPPENAS sebagai perencana pembangunan nasional dan BAPPEDA di propinsi dan kabupaten juga memiliki tanggung jawab kunci untuk konservasi keanekaragaman hayati. LSMLSM Indonesia telah memainkan peran aktif dalam merangsang ketertarikan umum dalam isu-isu keanekaragaman hayati. Di Indonesia terdapat lebih dari 400 LSM di seluruh nusantara yang bekerja bersama masyarakat lokal untuk menekan perusakan dan degradasi habitat alam, seperti rehabilitasi mangrove, pembinaan kawasan konservasi, pemberdayaan masyarakat di kawasan konservasi, penelitian-penelitian dan kajian kenakeragaman hayati dan kegiatan-kegiatan konservasi yang lainnya. ${ }^{46}$

Hambatan serius bagi keefekifan program-program konservasi ditinjau dari kelembagaan adalah banyaknya lembaga yang bertanggung jawab secara langsung

${ }^{46}$ Chip Fay \& Martua Sirait, "Mereformasi Para Reformis di Indonesia Pasca Soeharto", (Yakarta: Yayasan Obor Indonesia, 2003), hal.156-158. 
pada perlindungan keanekaragaman hayati dan kurang terkoordinasikannya lembaga-lembaga tersebut di dalam merencanakan dan melaksanakan program aksi konservasi keanekaragaman hayati. Selain itu dengan bergulirnya desentralisasi, maka diperlukan suatu mekanisme yang tepat yang mengatur keterkaitan antara lembaga yang ada di pusat dan yang di daerah di dalam program pengelolaan keanekaragaman hayati.

Secara umum pendanaan untuk pengelolaan sumberdaya hayati masih sangat terbatas, terutama semenjak krisis ekonomi tahun 1997, pendanaan untuk pengelolaan keanekaragaman hayati ini semakin terbatas. Pendanaan yang semakin terbatas ini sebagian besar dialokasikan ke kantor pusat dan taman nasional, yang alokasinya sebagian besar digunakan untuk membayar gaji staf. Bantuan pendanaan dari lembaga-lembaga donor secara umum juga masih terkonsentrasi pada kawasan taman nasional, inipun tidak tersebar secara merata, sedangkan pendaan unutk kawasan konservasi yang lain masih sangat terbatas. ${ }^{47}$

Jumlah sumberdaya manusia yang memadai secara kuantitas dan kualitas dalam pengelolaan keanekaragaman hayati juga masih terbatas dan belum tersebar merata. Hal ini juga menjadi hambatan besar di dalam pengelolaan keanekaragaman hayati. Apalagi jika dikaitkan dengan desentralisasi, maka jumlah dan kualitas sumberdaya hayati di daerah yang dapat diandalkan dalam pengelolaan sumberdaya hayati juga semakin terbatas.

\section{Penyelesaian Kolaboratif sebagai Solusi Terbaik}

Perkembangan pendekatan kolaborasi di Indonesia atau kemitraan istilah yang populer di Indonesia secara konseptual dan praktek sebenarnya telah menjadi perdebatan dan pengkajian yang intensif. Di Indonesia pada awal tahun 1990-an, manajemen kolaborasi yang lebih dikenal sebagai pola kemitraan sering dikonotasikan dengan manajemen inti-plasma antara petani dengan perusahaan perkebunan atau model bapak angkat antara pengusaha kecil dan pengusaha besar. ${ }^{48}$

Jika dilihat dari sejarahnya, perkembangan pendekatan kolaborasi mulai muncul sebagai respon atas tuntutan kebutuhan akan manajemen pengelolaan sumber daya yang baru, demokratis, lebih mengakui perluasan yang besar atas dimensi manusia dalam mengelola pilihan-pilihan, mengelola ketidakpastian, mengelola kerumitan dari potensi keputusan dan membangun kesepahaman, dukungan, kepemilikan atas pilihan-pilihan bersama. ${ }^{49}$

47 Sumardja, "Beberapa Sumbangan Pemikiran Untuk Pembentukan Sistem Taman Nasional", (Michigan: School of Natural Resources The University of Michigan, 1997), hal. 40.

${ }^{48}$ Suporahardjo, "Strategi dan Praktek Kolaborasi: Sebuah Tinjauan", (Bogor: Pustaka LATIN, 2005), hal.3.

${ }^{49}$ Julia M. Wondolleck dan Steven L. Yaffee, "Making Collaboration Work: Lesson from Innovation in Natural Resource Management", (California: Island Press, 2000), hal. 14. 
Oleh karena itu pendekatan kolaborasi ini sering disebut sebagai jembatan (bridges) untuk meningkatkan pengelolaan sumberdaya alam. Sebagai jembatan penyebrangan yang berfungsi mengintegrasikan batas-batas yang dibatasi oleh geografi, kepentingan dan persepsi. ${ }^{50}$

Secara lebih spesifik, Wondolleck dan Yafee misalnya, melihat pendekatan proses kolaborasi dari segi empat kegunaan utamanya, yaitu: ${ }^{51}$

Pertama, membangun pemahaman melalui peningkatan pertukaran informasi dan gagasan antara pemerintah, organisasi dan publik serta memberikan suatu mekanisme untuk penyelesaian ketidakpastian.

Kedua, memberikan suatu mekanisme untuk pembuatan keputusan yang efektif melalui proses-proses yang memfokuskan pada problem bersama dan membangun dukungan untuk keputusan.

Ketiga, menghasilkan suatu alat untuk membuat kerja yang bagus melalui koordinasi aktivitas lintas batas, meningkatkan manajemen bersama, dan memobilisasi suatu perluasan skenario sumber daya.

Keempat, pengembangan kapasitas lembaga pemerintah, organisasi dan komunitas untuk menghadapi tantangan-tantangan masa depan.

Ada tiga pola kemitraan yang munghkin terjadi pada organisasi seperti yang diidentifikasi oleh Huxham dan Macdonald, yaiatu: 1) koordinasi, dimana mungkin tidak ada interaksi langsung antara organisasi, tetapi dimana organiosasi mempertimbangkan kegiatan pihak yang lain dalam perencanaan yang dimilikinya; 2) $\mathrm{C} 0$-operation (kerja sama), dimana organisasi berinteraksi untuk mencapai misinya yang dimiliki mereka dan tujuan yang lebih efektif; 3) collaboration (kolaborasi) dimana organisasi bekerjasama untuk mencapai suatu meta-misi sementara juga mengejar misi dan tujuan yang bersifat individual yang mereka miliki. ${ }^{52}$

Di dalam konteks pengelolaan sumber daya alam pola kemitraan dikenal dengan skema "joint management" atau "co-management", atau "collaborative management". Kemitraan biasanya didefiniskan sebagai berbagai tanggung jawab dan/atau kewenangan antara pemerintah dan pengguna sumber daya lokal dalam mengelola sumberdaya tertentu. ${ }^{53}$

Spketrum manajemen kemitraan ini dapat dikelompokkan dalam beberapa tipe. Pertama, bersifat instruksi dimana ada pertukaran informasi yang minimal antara pemerintah dan pengguna.

Kedua, bersifat konsultasi, dimana ada mekanisme untuk pemerintah mengkonsultasikan dengan pengguna, tetapi seluruh keputusan masih dibuat oleh pemerintah.

${ }^{50}$ Ibid., hal.12.

51 Suporehardjo, "Manajemen Kolaborasi: Memahami Plurasisme Membangun Konsensus", (Bogor: Pustaka LATIN, 2005), hal.5.

${ }^{52}$ Ibid., hal.7.

${ }^{53}$ Ibid., hal.8. 
Ketiga, bersifat bekerjasama (cooperative) dimana pemerintah dan pengguna bekerjasama bersama-sama sebagai partner yang setara di dalam pembuatan keputusan. Tipe ini yang disebut sebagai pola kemitraan yang sesungguhnya.

Keempat, bersifat menasehati (advisory), pengguna memberikan saran kepada pemerintah atas sebuah keputusan yang seharusnya diambil dan pemerintah mendukung keputusan itu. ${ }^{54}$

Kesuksesan dalam mempraktekan pendekatan penyelesaian kolaborasi ini oleh Wondollack dan Yaffee, disebabkan karena beberapa alasan. ${ }^{55}$

Pertama, kolaborasi dapat berjalan sukses bila dapat membangun "common ground" (pandangan yang sama), kepentingan bersama atau menemukan cara menjembatani kecocokan kepentingan yang masih berbeda.

Kedua, pentingnya menciptakan kesempatan baru untuk berinteraksi. Misalnya melalui upaya membangun jalur komunikasi baru dan menetapkan struktur baru, baik melalui mekanisme formal maupun informal.

Ketiga, pentingnya melibatkan stakeholder ke dalam proses interaksi, bukan hanya produk akhir. Diyakini bahwa interaksi yang intensif dan berkualitas dalam proses pembuatan keputusan akan menghasilkan keputusan yang efektif dan menghasilkan kepuasan seluruh stakeholder.

Keempat, pentingnya memfokuskan mengatasi problem dengan cara-cara baru dan berbeda. Kebanyakan kolaborasi berhasil karena ada kemauan mencoba perilaku baru dan cara-cara berbeda dalam berinteraksi.

Kelima, pentingnya meningkatkan kepekaan terhadap tanggungjawab dan komitmen. Para pihak yang terlibat dalam kerja kolaborasi harus bekerja keras untuk mentransformasikan mereka (them) menjadi kami (us). Tantanganya adalah bagaimana menghentikan secara cepat dari situasi permusuhan diantara para pihak dan membantu terlibat dari pernyataan diri sebagai musuh menuju layaknya hidup bersama sebagai tetangga, yang akhirnya harus berkolaborasi.

Keenam, bentuk inti dari kemitraan yang kolaboratif adalah hubungan (relationship) antara individu-individu, bukan antara organisasi. Sehingga disimpulkan bahwa kemitraan adalah orang-orang yang bergabung berdasarkan hubungan. Karena oranglah yang dianggap mewakili lembaga pemerintah, organisasi atau pekerjaan di dalam suatu proses kolaborasi.

Ketujuh, banyak kasus kemitraan kolaboratif sukses karena upaya-upaya yang penuh dengan pengabdian, energik secara individual dengan pendekatan pro aktif dan berani memulai dengan upaya-upaya baru.

Kedelapan, banyak kasus kemitraan kolaboratif sukses karena orang-orang bersusaha mendapatkan dan mengakui pihak lain. Mereka mengusahakan dana dari luar dan mendaftar bantuan-bantuan yang dapat membantu mengelola proses

54 Jamie Ferguson dkk, Seminar Prospektus: Co-management and Resolving Conflict in Environmental Management, dalam website: <www.uogelph.ca/-jford01/6280/prospectus.pdf>, hal. 5., diakses tanggal 11 Februari 2011.

${ }^{55}$ Wondolleck dan Yaffee, Op. Cit., hal. 16. 
interaksi antara kelompok ketika mereka tidak mempunyai keahlian atau tidak yakin bagaimana memulainya.

Langkah-langkah yang perlu dilakukan dalam proses resolusi konflik diambil melalui kegiatan fasilitasi secara intensif untuk mendapatkan strategi penyelesaian melalui pola kolaboratif, yaitu: ${ }^{56}$

1. Merumuskan persepsi dan kronologis konflik secara lengkap

Sejarah kejadian yang lengkap menjadi dasar analisis untuk mendapatkan visi, misi, serta melakukan jajak pendapat antar stakeholder. Cara pandang masingmasing stakeholder menjadi dasar untuk memunculkan komitmen bersama, mencari alternatif penyelesaian terbaik.

2. Menggulirkan konsep Konsesi Rehabilitasi Terpadu sebagai solusi utama Pada tahap ini kelompok konservasi diharapkan muncul untuk menawarkan konsep rehabilitasi guna memulihkan kondisi dan menjaga keutuhan kawasan TNGL.

3. Membangun kerjasama dan kolaborasi dengan berbagai pihak

Kolaborasi dibutuhkan untuk mengawal proses penyelesaian, berbagi beban kerja, dan memberikan kesempatan kepada semua pihak untuk mengambil peran. Lebih penting lagi dari semua itu adalah menumbuhkan rasa tanggung jawab bersama dan mengaktualisasikan komitmen yang telah terbentuk pada tahap sebelumnya.

4. Tahapan pelaksanaan secara legal formal

Tahapan ini dilakukan setelah terjadi penguatan organisasi dalam bentuk manajemen kolaborasi yang dipandang cukup kuat untuk menjamin semua proses dan pelaksanaan kegiatan terjadi dengan semestinya.

5. Evaluasi dan Pemantauan

Evaluasi dan pemantauan dilakukan pada tiap tahap kegiatan.. Ada kemungkinan muncul alternatif penyelesaian lain sesuai perkembangan masalah yang terjadi. Evaluasi akhir dibutuhkan sebagai bahan refleksi untuk kegiatan selanjutnya.

Dibutuhkan strategi penanganan yang efektif. Strategi tersebut harus bisa dipastikan akan berjalan secara konsisten dan komprehensif. Pihak TNGL menawarkan strategi penyelesaian secara menyeluruh yang dilaksanakan bersama dalam suatu pola manajemen kolaboratif. Tahapan strategi adalah sebagai berikut: ${ }^{57}$

a. Penguatan organisasi melalui upaya fasilitasi untuk membangun pola kolaborasi

${ }^{56}$ Suporahardjo, dkk, "Inovasi Penyelesaian Sengketa Pengelolaan Sumber Daya Hutan", (Bogor: Pustaka LATIN, 2000), hal. 17-19.

${ }^{57}$ Wiratno, Penyelesaian Konflik di Taman Nasional Gunung Leuser Secara Kolaboratif, makalah disampaikan pada Sheared Learning di Tangkahan, Taman Nasional Gunung Leuser, 13 22 februari 2006, hal. 3-4. 
Target yang harus dicapai adalah pemaparan visi, misi, dan jajak pendapat masing-masih pihak, rapat koordinasi, pengumpulan data-data primer/ sekunder, hingga pembentukan tim penyelesaian

b. Relokasi pengungsi

pekerja perambah. Aspek lain yang perlu diselesaikan dalam upaya relokasi yaitu penyediaan dana terminasi dan pendampingan pengungsi di lokasi baru.

c. Penangkapan dan penegakan hukum bagi perambah

d. Pelaksanaan relokasi dilakukan setelah proses penyiapan lokasi baru bagi pengungsi sudah mendapat kepastian. Selanjutnya dilakukan sosialisasi relokasi secara terpadu dan penanganan awal bagi penduduk non pengungsi termasuk para

e. Pada saat lain, pihak yang berwenang melakukan penangkapan aktor intelektual, juga para perambah dan memastikan proses hukum berjalan. Proses ini memerlukan

f. Beberapa kegiatan dalam isolasi kawasan ini adalah: penutupan kawasan dengan membangun pos jaga dan membentuk satuan pengamanan swakarsa, dan sosialisasi awal untuk proses selanjutnya yaitu rehabilitasi.

g. Rehabilitasi diawali dengan pembersihan lokasi bekas pengungsi dan perambah. Setelah pengukuran batas dan luas kerusakan, rehabilitasi bisa dilaksanakan sesuai data tentang siapa pengungsi dan siapa perambah, mengingat mereka telah membaur di dalam pemukiman.

h. Isolasi Kawasan

i. Rehabilitasi Kawasan

dengan rencana kegiatan rehabilitasi yang telah disusun bersama, termasuk teknis perawatan tanaman nantinya.

j. Community Development

Kegiatan pendampingan dan penyadaran perlu secara intensif dilakukan pada masyarakat di sekitar areal rehabilitasi. Jangan sampai kejadian serupa terulang. Diharapkan dengan pola community development terbangun hubungan timbal balik yang harmonis antara manusia dengan alam, antara masyarakat dengan kawasan taman nasional.

Sesuai dengan arah kebijakan dan strategi pengelolaan konservasi pada program pembangunan kehutanan bidang Perlindungan Hutan dan Konservasi Alam, selain 3 pilar konservasi yaitu fungsi perlindungan, pengawetan dan pemanfaatan secara lestari, diperlukan dukungan dalam peningkatan pemberdayaan masyarakat dan pengembangan mekanisme penyelesaian konflik.

Melalui kegiatan ini diharapkan dapat menghasilkan suatu arahan dan strategi yang merupakan hasil kesepakatan bersama, bersifat partisipatif, kolaboratif dan memiliki akuntabilitas serta dilaksanakan sesuai dengan komitmen yang telah dibangun secara bersama-sama pula. Arahan dan strategi inilah nantinya yang akan dipakai dalam penyelesaian masalah secara menyeluruh 
sehingga kawasan dapat direhabilitasi dan kembali berfungsi seperti semula sebagai kawasan konservasi.

Dalam era keterbukaan ini pengelolaan didasarkan pada paradigma baru yaitu community based management dan participatory approach. Pengelolaan konservasi melibatkan banyak komponen instansi dan masyarakat untuk mendapatkan sinergi dalam pelaksanaannya. Strategi partisipatif, kolaboratif dan akuntabilitas diterapkan untuk menghimpun kebersamaan seluruh komponen bangsa dalam berperan mulai dari perencanaan hingga pelaksanaan juga dalam monitoring dan evaluasinya. Pelibatan masyarakat diharapkan mulai dari individu, kelompok, LSM, pemerhati dan pelaku ekonomi sehingga semuanya akan memiliki rasa tanggung jawab untuk keberhasilannya.

Strategi ini menjadi sangat penting dan bisa aplikatif dalam upaya mengawal perjalanan otonomi daerah, karena setiap daerah juga diharapkan terlibat dalam pengelolaan konservasi. Dengan pola seperti ini diharapkan konflik antar instansi dan masyarakat dapat dihindari dan ditemukan jalan keluar penyelesaian konflik yang terjadi. Pengelolaan konservasi ini sangat membutuhkan harmonisasi berbagai pihak, sehingga diperlukan keterbukaan (akuntabilitas) dari dan kepada semua pihak.

Potensi dari sumber daya alam yang terdapat di kawasan, dan dibandingkan dengan lokasi yang sama di Kabupaten Langkat, maka Tangkahan dapat menjadi sebuah kawasan Ekowisata bila dikembangkan dengan baik. Hal ini didukung oleh informasi yang didapatkan dari Buku Panduan Sumatera Utara yang ditulis oleh Mahmud Bangkaru. Menurutnya Tangkahan adalah alternatif lain bagi Bukit Lawang. melalui perencanaan yang partisipasif dan ramah lingkungan. Diharapkan bahwa Tangkahan dapat berkembang menjadi kawasan ekowisata dan wisata alam yang baru. ${ }^{58}$

Obyek wisata alam di kawasan Tangkahan yang telah diidentifikasi oleh pemerintah daerah tingkat II Kabupaten Langkat adalah Pemandian Sei Buluh. $\mathrm{Hal}$ ini menunjukkan bahwa informasi mengenai kawasan masih sangat terbatas. Sementara obyek wisata alam dan wisata minat khusus lainnya yang dapat dikemas menjadi Produk-produk Ekowisata yang dapat dikembangkan,telah diindentifikasi oleh Lembaga Pariwisata Tangkahan.

Produk ekowisata tersebut meliputi: $:^{59}$

a. Produk wisata Petualangan

Produk wisata ini bertujuan untuk menambah pengalaman menjelajah hutan hujan tropis dataran rendah dan peningkatan pengetahuan mengenai jenis-jenis satwa yang terdapat di Taman Nasional. jalur jalan setapak akan menyediakan sarana untuk berpetualang dan juga menaramenara pengamatan satwa, diakhir perjalanan produk wisata ini dapat pula ditambahkan dengan menyusur goa dan tubing. Produk ini hanya akan diperuntukan bagi mereka yang memiliki standar kesehatan dan

\footnotetext{
${ }^{58}$ Ibid., hal. 4-6.

${ }^{59} \mathrm{Ibid}$.
} 
stamina yang baik. Produk wisata ini dapat juga dilakukan dengan paket Elephant Riding Patroll dengan empat ekor Gajah Leuser CRU (Conservations Respons Unit) kerjasama Flora dan Fauna Internationals dengan Balai KSDA, Balai TNGL dan Lembaga Pariwisata Tangkahan.

b. Produk Wisata Agro

Produk wisata Agro yang dapat dikembangkan diantaranya adalah mengunjungi perkebunan tanaman keras dan buah milik masyarakat. Melalui kegiatan ini dan pengetahuan pengunjung akan kegiatan perkebunan penduduk dapat ditingkatkan.Jalur-jalur Interpretasi wisata Agro yang disiapkan melalui wawasan berbagai jenis perkebunan masyararakat sekaligus mendapatkan pengalaman langsung dilapangan untuk memetik hasilnya,seperti menyadap karet,memetik jeruk, Durian dan lainnya.kegiatan ini dapat dilakukan dengan berjalan kaki, berkuda dan bersepeda.Dan dapat juga dilakukan Interpretasi di Perkebunan Kelapa Sawit dan Karet milik BUMN maupun Swasta yang terdapat di Kawasan Ekowisata dengan menerangkan proses Hulu sampai Hilir Produksinya. Hal ini dapat menjadi mamfaat ganda bagi Masyarakat maupun pengunjung

c. Produk Wisata Tirta

Dikawasan Tangkahan terdapat sungai-sungai yang memberikan peluang untuk dikembangkanya Wisata Tirta.seperti wisata pemandian yang telah berkembang saat ini.Tujuan dari wisata tirta ini lebih banyak untuk mendapatkan unsur rekreasi,sehingga biasanya bersifat masal (pada kawasan-kawasan tertentu yang telah ditunjuk )beberapa kegiatan dari widsata tirta yang dapat dilakukan diTangkahan adalah berenang,menyusuri Sungai dengan Tubbing (ban karet) dan paket safari sungai dengan Rubber boat dengan Standard safety Pelampung, helmet dan team Rescue. Dan tidak tertutup kemungkinan untuk pengembangan Rafting, kayaking/canoing.

d. Berkemah

Dalam hal berkemah di Tangkahan akan dikembangkan dua jenis perkemahanan. Pertama adalah perkemahan masal yang akan dikembangkan pada lokasi yang jauh dari Taman Nasional dan secara Zonasi pun merupakan Zonasi untuk kegiatan Rekreasi,akan tetapi nilainilai kebersihan,pelestarian kawasan dan juga kemungkinan sistem reservasi akan mulai diberikan secara bertahap. Sementara jenis yang kedua adalah Perkemahan terbatas yang terdapat didalam Taman Nasional,didalam perkemahan ini pengunjung akan benar-benar belajar berkemah yang ramah lingkungan yang tidak menimbulkan dampak negatif terhadap Flora Fauna di Taman Nasional dengan sistem Reservasi yang terbatas.

e. Produk wisata Budaya

Merupakan salah satu Produk wisata yang juga dapat ditawarkan di Kawasan Ekowisata Tangkahan. Tujuan dari produk wisata ini adalah 
pengunjung dapat mempelajari serta meningkatkan Apresiasi terhadap Adat istiadat karo,kesenian Karo dan pengobatan tradisional serta kearifan masyarakat lokal.

Proses pengembangan Kawasan Ekowisata Tangkahan pada prinsipnya dilakukan sepenuhnya oleh masyarakat lokal. Adapun model dan ruang lingkup Partisipatif masyarakat dalam mengembangakan Kawasan Ekowisata Tangkahan dapat dilihat dalam tabel di bawah ini. Bukti bahwa pengembangan kawasan ekowisata Tangkahan ini dilakukan sepenuhnya oleh masyarakat lokal, dapat dibuktikan oleh beberapa hal.

Pertama, peningkatan kapasitas dan kemampuan masyarakat. Kegiatan yang dilakukan untuk meningkatkan kapasitas dan kemampuan masyarakat lokal berupa: pendidikan, pelatihan dan studi banding serta mengikuti berbagai forum dan event diberbagai tingkatan dengan bantuan dan kerjasama berbagai pihak (BTNGL, Disbudpar, UML, INDECON, FFI,CII, PAN ECO, dan lainnya).

Kedua, peningkatan pendapatan masyarakat. Peningkatan pendapat masyarakat tersebut dilakukan dengan: 1) terbukanya peluang usaha di bidang Pariwisata alam jasa, obyek dan daya tarik serta sarana dan prasarana, 2) memacu pembangunan wilayah setempat baik tingkat local, regional maupun nasional, 3) berkembangnya mitra usaha investasi dengan masyarakat disekitarnya dan terbukanya akses pasar, 4) terjaminya kesinambungan usaha, 5) memberikan keuntungan ekonomi bagi para pengelola kawasan, pengusaha pariwisata alam dan masyarakat setempat, 6) menciptakan multiflier effect bagi berbagai sector ikutan di berbagai tingkatan.

Ketiga, peningkatan peran serta masyarakat, dengan menciptakan partisipasi kolektif masyarakat di Desa Namo Sialang dan Desa Sei.Serdang melalui Peraturan Desa.

Keempat, menciptakan keuntungan dan manfaat bagi masyarakat. Partisipasi masyarakat mulai dari perencanaan, pelaksanaan, monitoring dan evaluasi. Mempertemukan antara penawaran obyek dan daya tarik wisata alam sebagai produk ekowisata dengan permintaan pasar sehingga dapat memberikan mamfaat pada para pihak yang seharusnya terlibat terutama masyarakat.

Kelima, meningkatkan kapasitas dan penguatan pengelolaan. Peningkatan kapasitas Lembaga Pariwisata Tangkahan dalam pengelolaan kawasan secara intensif dan komprehensif.

Arah dan alur pengembangan Investasi di Kawasan Ekowisata Tangkahan adalah berorientasi pengembangan mikro ekonomi pedesaan. Sehingga diharapkan dikedepannya dapat mengarahkan kebijakan pembangunan Daerah dan Nasional di pedesaan-pedesaan yang berbatasan dengan Taman Nasional. Dan kawasan disekitar Taman Nasional dapat menjadi kawasan perekonomian yang menggairahkan (ekologi-cluster). Untuk menuju kearah sana membutuhkan kerja keras dan sangat panjang sehingga dibutuhkan infrastruktur social yang konsisten dan berkesinambungan dalam sebuah manajemen terpadu dan kolaboratif. Diharapkan dikedepannya akan disepakati bersama oleh berbagai pihak untuk dapat membentuk sebuah Badan Investasi Kawasan sebagai manajemen penataan dan pengendalian serta mengoptimalisasi potensi investasi dan modal di Kawasan Ekowisata Tangkahan. disamping memiliki tujuan untuk dapat mempromosikan 
dan membuka pintu bagi investasi dari luar dengan tetap dapat mempertahankan orientasi ekologi dan peranan masyarakat lokal secara berkelanjutan..

Selama proses perencanaan pengembangan pariwisata di tingkat masyarakat, telah disusun bersama-sama antara masyarakat lokal dan Balai Taman Nasional. Antisipasi dampak pengembangan wisata diantaranya adalah:

a. Mengurangi dampak penggunaan kawasan dengan cara membuat zonazona di kawasan pengembangan secara tidak langsung telah membatasi pengunjung yang masuk ke kawasan-kawasan yang rentan.

b. Membuat peraturan di tingkat desa dan dikuatkan dengan peraturan di tingkat daerah, tentang pembatasan pembangunan sarana dan prasarana, yang didasarkan pada hasil zonasi dan kesepakatan bersama.

c. Mengatur tipe pemanfaatan dan perilaku pengunjung, seperti mengajarkan etika di alam bebas, mengatur jumlah orang dalam satu kelompok, dan lain-lain.

d. Mengatur harapan pengunjung, hal ini dapat dicapai dengan cara memberikan informasi mengenai apa yang harus dipakai/digunakan oleh pengunjung, dan memberikan informasi tentang keadaan yang akan mereka hadapi.

Pengelolaan secara kolaboratif ini nampak jelas diatur dalam Pasal 3 Peraturan Desa yang menyatakan bahwa Kawasan Ekowisata Tangkahan dikelola menurut azas dan prinsip kebersamaan, keterbukaan, kekeluargaan, dan mengedepankan kepentingan bersama menurut aturan dan mekanisme yang telah disepakati.

Berdasarkan kesepakatan bersama masyarakat Desa Namo Sialang dan Desa Sei Serdang untuk membentuk Lembaga Pariwisata Tangkahan pada tanggal 19 Mei 2001 sebagai lembaga masyarakat lokal, maka Pemerintah Desa Namo Sialang dan Desa Sei Serdang menetapkan beberapa hal.

Pertama, Lembaga Pariwisata Tangkahan disingkat LPT adalah lembaga resmi yang mengelola Kawasan Ekowisata Tangkahan.

Kedua, Pengelolaan ekowisata dalam Kawasan Tangkahan Taman Nasional Gunung Leuser dilaksanakan secara bersama-sama antara Lembaga Pariwisata Tangkahan dan Balai Taman Nasional Gung leuser.

Ketiga, di dalam pelaksanaannya, Lembaga Pariwisata Tangkahan dan Balai taman Nasional Gunung Leuser dapat bekerjasama dengan para pihak terkait melalui kesepakatan bersama yang disusun menurut mekanisme dan aturan yang berlaku.

Keempat, mengenai masalah Lembaga Pariwisata Tangkahan diatur dalam Anggaran Dasar dan Anggaran Rumah Tangga (AD/ART) Lembaga Pariwisata Tangkahan.

Pengaturan tentang pengelolaan kawasan Tangkahan secara kolaboratif ini tampak jelas dilihat dalam kententuan yang terdapat dalam Perdes. Dalam ketentuan tersebut dinayatkan bahwa seluruh masyarakat berkewajiban untuk melindungi, menjaga dan melestarikan tempat-tempat yang telah ditetapkan sebagai Lubuk Larangan di Kawasan Ekowisata Tangkahan dan dapat dimanfaatkan untuk kegiatan memancing, dimana dalam penyelenggaraannya 
melalui mekanisme dan aturan sebagaimana ditetapkan oleh Lembaga Pariwisata Tangkahan (LPT) dan Balai Taman Nasional Gunung Leuser untuk kawasan di dalam Taman Nasional dan Pemerintahan Desa untuk kawasan di luar Taman Nasional (Pasal 9).

Ketentuan tersebut menunjukkan bahwa adanya kolaborasi dalam mengelola kawasan Tangkahan. Pengelolaan ini cukup efektif dan mempunyai hasil yang signifikan, bila dibandingkan dengan penyelesaian yang lain seperti mediasi dan musyawarah. Meskipun kedua penyelesaian tersebut tidak bisa diabaikan begitu saja, karena keduanya merupakan latar belakang lahirnya penyelesaian dan pengelolaan kawasan Tangkahan yang dilakukan secara kolaboratif.

Dalam rangka meningkatkan manfaat masyarakat lokal akan hutan, maka ada suatu ketentuan untuk melestarikan ekosistem di luar kawasan Tangkahan, dimana masyarakat berkewajiban untuk menyelenggarakan hutan-hutan cadangan dengan tanaman produktif dan berdaya guna untuk ekowisata dan pertanian masyarakat (Pasal 10). Disamping itu seluruh masyarakat dan Balai Taman Nasional Gunung Leuser berkewajiban untuk menentang dan melarang upaya pertambangan yang dilakukan di dalam Kawasan Tangkahan Taman Nasional Gunung Leuser.

Hal lain yang menarik untuk dikembangan secara kolaboratif meskipun tanpa harus meninggalkan keaslian adat istiadat Suku Karo, maka masyarakat lokal bekerjasama dengan pihak Balai Taman Nasional dengan didukung oleh Indecon melakukan upaya penguatan, pelestarian dan penggunaan budaya lokal. Adapun hal-hal yang dilakukan dalam rangka penguatan dan pelestarian budaya lokal adalah

a. Setiap ada kunjungan wisata atau kunjungan dari pihak luar, maka masyarakat lokal senantiasa menampilkan dan menyajikan upacara adat seperti Marga Silima, Tutur Siwaluh, Rakut Sitelu dan Sumbang Sisiwah.

b. Rumah adat suku karo yang sudah semakin sulit didapatkan saat ini, dicoba untuk disosialisasikan dan dilestarikan meskipun saat ini cukup sulit ditemukan di masyarakat di kedua desa yaitu Desa Namo Sialang dan Desa Sei Serdang.

c. Pada upacara adat, baik untuk menyambut para tamu, upacara perkawinan, atau upacara adat lainnya maka senantiasa menggunakan pakaian adat sesuai acara adat tersebut. Hal ini agar tetap menjaga keaslian adat Karo yang memang menjadi mayoritas penduduk di kedua desa tersebut.

Upacara adat tersebut merupakan kegiatan yang rutin diselenggarakan setiap ada tamu wisatawan dan setiap ada upacara adat resmi yang diselenggarakan oleh masyarakat disuatu tempat di atas sungai Batang Serangan. Setiap masyarakat/pengunjung pendatang diwajibkan untuk menghormati tata cara dan adat istiadat yang berlaku di Kawasan Tangkahan. Masyarakat mempercayai apabila ini dilanggar maka akan menimbulkan sesuatu yang tidak baik yang akan menimpa masyarakat lokal maupun pengunjung/pendatang tersebut. 


\section{Kesimpulan}

Pengelolaan sumber daya hutan di berbagai kawasan Taman Nasional di beberapa kawasan sering kali menimbulkan persoalan. Persoalan tersebut antara lain adalah adanya konflik pemanfaatan sumber daya hutan. Konflik yang terjadi antara lain disebabkan oleh karena adnya tumpang tindih berbagai peraturan baik antara Undang-Undang dengan Peraturan Pemerintah, maupun antara Peraturan Pemerintah dengan Peraturan Daerah.

Akibat dari adanya tumpang tindih antara berbagai peraturan, menimbulkan adanya pemahaman yang salah tentang bagaimana seharusnya mengelola hutan, baik oleh Pemerintah Pusat, Pemerintah Daerah, serta masyarakat lokal yang tinggal dikawasan hutan.

Oleh karena itu dalam menyelesaikan konflik yang terjadi, karena pengelolaan sumber daya hutan maka solusi yang paling baik adalah menerapkan pola penyelesaian kolaborasi/kemitraan, antara masyarakat lokal dengan pemerintah. Dalam kasus yang terjadi di Tangkahan maka masyarakat lokal menyelesaikan dengan penyelesaian kolaboratif antara Balai Taman Nasional dengan masyarakat lokal. Penyelesaian kolaboratif tersebut dapat dibuktikan dengan pengelolaan ekowisata di kawasan Tangkahan, yang sampai saat ini cukup berjalan dengan baik meskipun masih perlu ditingkatkan lagi. 


\section{Daftar Pustaka}

Aditjondro, George Junus. Pola-Pola Gerakan lingkungan: Refleksi Untuk Menyelematkan Lingkungan Dari Ekspansi Modal, Yogyakarta: Pustaka Pelajar, 2003. 2003.

. Korban-Korban Pembangunan, Yogyakarta: Pustaka Pelajar,

Askin, Moh. Penegakan Hukum Lingkungan dan Pembicaraan di DPR-RI, Jakarta: Yasrif Watampoene, 2003.

Atmasasmita, Romli. Kapita Selekta Hukum Pidana Internasional, Bandung: CV. Utomo, 2004.

. Pengantar Hukum Pidana Internasional, Bandung: PT. Refika Aditama, 2003.

Awang, San Afri, dkk, Gurat Hutan Rakyat di Kapur Selatan, Yogyakarta: CV Debut Press, 2001.

Baswir, Revrisond, dkk, Pembangunan Tanpa Perasaan: Evaluasi Pemenuhan Hak Ekonomi, Sosial, dan Budaya, Jakarta: ELSAM, 2003.

Bruggink, H.J.J. Refleksi Tentang Hukum, Alih Bahasa Arief Sidharta, Bandung: PT. Citra Aditya Bakti, tanpa tahun.

Bruce, Mitchell, B. Setiawan dan Dwita Hadi Rahmi, Pengelolaan Sumberdaya dan Lingkungan, Yogyakarta: Gadjah Mada University Press, 2003.

Bruce, Rich. Menggadaikan Bumi, tanpa kota: Infid, 1999.

Budiarjo, dkk. Reformasi Hukum di Indonesia, Jakarta: Cyber Consult, 2000.

Cotterel, Roger. Law's Community, Legal Theory in Sociological Perspective, Oxford: Clarendo Press, 1995.

Departemen Kehutanan. Nuansa dan Harapan Reformasi Kehutanan dan Perkebunan, Perjalanan 250 hari Menuju Pengelolaan Sumber Daya Alam Yang Berkelanjutan dan Berkeadilan, 1999.

Dey, Thomas R. Understanding Public Policy, New Jersey: Engelwoodcliff Hall, 1978.

Direktorat Jenderal Perlindungan Hutan dan Pelestarian Alam, Taman Nasional Di Indonesia, 1994.

Donald, Black, \& Maureen Mileski (Eds). The Social Organization of Law, New York: Seminar Press, 1973. 
Fauzi, Noer, dan I Nyoman Nurjaya, Sumber Daya Alam Untuk Rakyat: Modul Lokakarya Penelitian Hukum Kritis-Partisipatif bagi Pendamping Hukum Rakyat, Jakarta: ELSAM, 2000.

Fitzduff, Mari. Keterampilan Komunitas Dalam Menghadapi Konflik: Buku Pegangan untuk Kerja Kelompok di Irlandia Utara, Jakarta: British Council, 2002

Fisher, Simon. Mengelola Konflik: Keterampilan dan Strategi Untuk Bertindak, Indonesia: The British Council, 2001.

Fuad, Faisal H. dan Siti Maskanah. Inovasi Penyelesaian Sengketa Pengelolaan Sumber Daya Hutan, Pustaka LATIN, 2000.

Hadi, Sudharto P. Resolusi Konflik Lingkungan. Semarang: Badan Penerbit UNDIP, 2004.

Hashim, Ben Phillips, dan wahyu Widodo. Program-Program Daerah Penyangga, Work Shop, Program daerah penyangga, Bogor, 17-28 Oktober, 1992.

Heroepoetri, Arimbi, Julia Kalmirah dan Niken Sekar Palupi, Seri Konvensi Internasional Lingkungan: Konvensi Washington, Konvensi Keanekaragaman Hayati, Konvensi Perubahan Iklim, Jakarta: Wahana Lingkungan Hidup Indonesia (WALHI) bekerjasama dengan FH UNIKA Atmajaya, 1999.

Heydir, Lauriel, dkk, Pengakuan Hak-Hak Masyarakat Untuk Pengembangan Community Forestry Abad 21, Yogyakarta: Aditya Media, 1999.

Iskandar, Untung. Poltik Pengelolaan Sumberdaya Hutan: Issue dan Agenda Mendesak, Yogyakarta: Debut Press, 2004.

Kasim, Ifdhal, dan Johanes da Masenus Arus. Hak Ekonomi, Sosial, Budaya, Jakarta: Lembaga Studi dan Advokasi Masyarakat (ELSAM), 2001.

Kodra, Hadi S. Ali, dan Syaukani. Bumi Makin Panas Banjir Makin Luas, Yayasan Nuansa Bandung: Cendekia, 2004.

Kuncoro, Mudrajad. Otonomi Daerah dan Pembangunan Daerah: Reformasi, Perencanaan, Strategi, dan Peluang, Jakarta: Penerbit Erlangga, 2004.

Kusumaatmadja, Mochtar. Konsep-Konsep Hukum Dalam Pembangunan, Bandung: PT. Alumni, 2002.

Kusworo, Ahmad. Perambah Hutan atau Kambing Hitam?: Potret Sengketa Kawasan Hutan di Lampung, Bogor: Pustaka Latin, 2000.

Malik, Ichsan, dkk, Menyeimbangkan Kekuatan: Pilihan Strategi Menyelesaikan konflik Atas Sumber Daya Alam, Jakarta: Yayasan Kemala, 2003. 
Moelyono, Ilya, dkk, Memadukan Kepentingan Memenagkan Kehidupan, Bandung: Driya Media, 2003.

Mulyadi, Kartini, dan Gunawan Widjaya, Hak-Hak Atas Tanah, Jakarta: Prenada Media, 2004.

Owen, J. Linch, dan Kirk Talbott, Keseimbangan Tindakan: Sistem Pengelolaan Hutan Kerakyatan dan Hukum Negara di Asia dan Pasifik, Jakarta, ELSAM, 2001.

Riyatno. Perdagangan Internasional dan Lingkungan Hidup, Jakarta: Universitas Indonesia, 2005.

Riyanto, Budi. Selayang Pandang Pengelolaan Kawasan Hutan di Indonesia, Bogor: Lembaga Pengkajian Hukum Kehutanan dan Lingkungan, 2004.

- Pengaturan Hukum Adat di Indonesia, Lembaga Pengkajian Hukum Kehutanan dan Lingkungan, Bogor, 2004.

- Pengelolaan Kawasan Suaka Alam dan Kawasan Pelestarian Alam, Sebuah Tinjauan Hukum Terhadap Debt for nature Swaps, Lembaga Pengkajian Kehutanan dan Lingkungan, Bogor, 2004.

. dan Dudi Mempawardi saragih. Tanya Jawab Lengkap Hukum Konservasi Hayati, Lembaga Pengkajian Hukum Kehutanan dan Lingkungan, Bogor, 2004.

- Himpunan Ringkasan Peraturan Perundang-Undangan di BIdang Kehutanan dan Konservasi Hayati, Lembaga Pengkajian Hukum Kehutanan dan Lingkungan, Bogor, 2004.

- dan Samedi. Dinamika Konservasi Hayati di Indonesia, Lembaga Pengkajian Hukum Kehutanan dan Lingkungan, Bogor, 2004.

Safitri, Myrna A. Desa, Institusi Lokal dan Pengelolaan Hutan: Refleksi Kebijakan dan Praktik, Jakarta: ELSAM, 2000.

Saman, Efendi, dkk, Politik Hukum Penguasaan Hutan di Indonesia, Jakarta: Wahana Lingkungan Hidup Indonesia (WALHI), 1993.

Santosa, Mas Achmad, dan Sulaiman Sembiring, Pengaduan Masyarakat dan Penyelesaian Sengketa Lingkungan, Jakarta: Indonesian Center for Environmental Law (ICEL), 1997.

Sardjono, Mustofa Agung. Mosaik Sosiologi Kehutanan: Masyarakat Lokal, Politik dan Kelestarian Sumberdaya Yogyakarta: Debut Press, 2004.

Schaffmeister, D, Kekhawatiran Masa Kini: Pemikiran Mengenai Hukum Pidana Lingkungan Dalam Teori dan Praktek, Diterjemahkan oleh Tristam P. Moeliono, Bandung: PT. Citra Aditya Bhakti, 1994. 
Shawcross, Shaw Dj. William. Deliver US From Evil: Worlords and Peacekeepers In A World Of Endless Conflict, London: Bloomsbury Publishing, 2000

Storey, Gordon dan A. Marzuki, Survey Sosial Ekonomi Masyarakat Sekitar Hutan: Contoh untuk Perencanaan dan Pelaksanaan di Tingkat Operasional, Jakarta: Departemen Kehutanan, 2002.

Suhardjito, Didik. Hak-Hak Penguasaan Atas Hutan di Indonesia, Bogor: P3KM, 1999. . dkk, Pengelolaan Hutan Berbasiskan Masyarakat, Yogyakarta, Aditya Media, 2000.

Susanti, Ari, dkk, Proceeding Lokakarya Pengelolaan Hutan Bersama Masyarakat, Yogyakarta: Lembaga ARUPA, 2000.

Tim Peneliti CIFOR, Analisa Konflik Kehutanan di Indonesia 1997-2003, CIFOR, 2004.

Tim Peneliti ARUPA. Proceeding Lokakarya Pengelolaan Hutan Bersama Masyarakat, Lembaga ARUPA, Yogyakarta, 2000.

Whittaker, David, J. Conflict and Reconciliation in the Contemporary World: Making of the Contemporary World, Cornwall: TJ International Ltd, 1999.

Wiratno, dkk, Berkaca di Cermin Retak: Refleksi Konservasi dan Implikasi Bagi Pengelolaan Taman Nasional, Jakarta: FORest Press, 2004.

Wulan, Yuliana Cahya. dkk, Analisa Konflik sector kehutanan di Indonesia 1997-2003, Bogor: Center for International Forestry Research, 2004. 